\title{
A review on importance of bioactive compounds of medicinal plants in treating idiopathic pulmonary fibrosis (special emphasis on isoquinoline alkaloids)
}

\author{
Sai Sushma Dudala', T. C. Venkateswarulu', Sushma Chandulee Kancharla², Vidya Prabhakar Kodali ${ }^{3^{*}}$ and \\ D. John Babu ${ }^{1 *}$ (D)
}

\begin{abstract}
Background: Idiopathic pulmonary fibrosis (IPF) is a fatal lung disease of unknown cause which disrupts the normal lung architecture and functions by deregulating immune responses and ultimately leads to the death of the individual. A number of factors can lead to its development and currently there is no cure for this disease.

Main text: There are synthetic drugs available to relieve the symptoms and decelerate its development by targeting pathways involved in the development of IPF, but there had also been various side effects detected by their usage. It is known since decades that medicinal plants and their compounds have been used all over the world in natural medicines to cure various diseases. This review article is focused on the effects of various natural bioactive compounds of 26 plant extracts that show prophylactic and therapeutic properties against the disease and so can be used in treating IPF replacing synthetic drugs and reducing the side effects.

Short conclusion: This review includes different mechanisms that cause pulmonary fibrosis along with compounds that can induce fibrosis, drugs used for the treatment of pulmonary fibrosis, diagnosis, the biochemical tests used for the experimental study to determine the pathogenesis of disease with a special note on Isoquinoline alkaloids and their role in reducing various factors leading to IPF thus providing promising therapeutic approach.
\end{abstract}

Keywords: Pulmonary Fibrosis, Idiopathic, Isoquinoline, Berberine

\section{Background}

Fibrosis is the surplus development of fibrous connective tissue in an organ that interferes or inhibits the normal function and architecture of the underlying organ or tissue. Fibrosis arises from a single cell line called fibromas which are benign tumours and are composed of fibrous or connective tissue. Rising from mesenchymal tissue,

\footnotetext{
* Correspondence: kodalividyaprabhakar@gmail.com;

johnbabud77@gmail.com

${ }^{3}$ Department of Biotechnology, Vikrama Simhapuri University, Nellore,

Andhra Pradesh 524320, India

'Department of Biotechnology, Vignan's Foundation for Science, Technology and Research, Vadlamudi, Guntur, Andhra Pradesh 522213, India

Full list of author information is available at the end of the article
}

they can grow at any organ or tissue [1]. The formation of fibromas in the lungs is termed pulmonary fibrosis, which is also known as idiopathic pulmonary fibrosis (IPF). IPF is a disease or condition which arises spontaneously for which the cause is unknown. IPF is a progressive, age-related, devitalizing lung disorder that is fatal with a high mortality rate. Different disorders can arise during the wound healing process of the damaged or scarred lung tissue which can be characterized as fibroblasts differentiation, infiltration of inflammatory cells, extracellular matrix remodelling and collagen deposition [2]. In general, the extracellular matrix (ECM) is mainly constituted by collagens and it gives strength to the tissues. Amino acids such as glycine, proline and lysine 
enable its formation. Non-elastin and proteoglycans like glycosamino glycans are essential to matrix resiliency. Enzymes and glycoproteins are useful to create tissue cohesiveness [3]. Epithelial mesenchymal transition (EMT) is one of the factors that thicken the lung tissue making it difficult to work properly and as fibrosis worsens, it will ultimately lead to shortness of breathing. Various additional conditions co-occurring with IPF are pulmonary hypertension, gastro-oesophageal reflux, coronary artery disease, malignancy, telomeropathy, pleuroparenchymal fibroelastosis and hypoxaemia [4]. There is a higher chance of getting affected with lung cancer in IPF because of mutation in the p53 tumour suppressor gene, which is involved in DNA repair, apoptosis and cell proliferation and differentiation [5].

IPF treatment remains unsatisfactory due to few treatment options and therapeutic measures, whereas in critical cases, lung transplantation is the only cure. There is no specific drug to cure IPF, but the drugs currently available are used only to reduce the symptoms by targeting specific pathways that led to IPF. Hence, there is a substantial need to discover various novel means to treat chronic lung diseases and at the same time reduce the side effects caused by the use of available drugs.

Medicinal plants and their compounds have been used all over the world in natural medicines to cure various diseases. Moreover, their usage is increasing in modern society as an alternative remedy for synthetic chemicals. These are also being commercialized on a large scale in various forms as medicines, cosmetics, ointments, essential oils in therapy etc., due to their useful properties. In addition, treating diseases with medicinal plant extracts is cost effective and has fewer side effects. Apart from this, the biological activity of any plant, its compounds and their effect on health can be known through research. Many plants are used across the globe in traditional medicine to cure various diseases and are also used in various therapies related to lung diseases. Examples of some plants used in treating lung diseases are Papaver somniferum for cough, cramps; Lobella spp for asthma; Ephedra spp. in respiratory alignments; Coffea arabica as a stimulant etc. Likewise, various plants and their extracted oils and compounds are used in treating various lung diseases [6]. Hence, this review focuses on pulmonary fibrosis and its mechanisms, chemicals that induce fibrosis, diagnosis, the synthetic treatment and details of natural plants and its compounds used to treat IPF with a special note on isoquinoline alkaloids.

\section{Pulmonary fibrosis and mechanisms involved in its development}

Pulmonary diseases are caused due to an imbalance and dysregulation of various immune response mechanisms in the body, and if these disturbances persist for a long time, these lead to pulmonary fibrosis. The mechanisms leading to IPF include the following

\section{Disturbances in the regular wound healing process}

Wound healing is an essential process for the repair of the skin and the tissues underlying it after injury. The healing process undergoes four different stages: coagulation/clotting phase, migratory phase of inflammatory cells, proliferation/activation/migration phase of fibroblast, remodelling and resolution phase of tissue. Each process is regulated by different growth factors and cytokines. As the focus of the review is on pulmonary fibrosis, the wound healing mechanism with respect to lung fibrosis is shown in Fig. 1 [7]. Injury to lung epithelial cells enables the release of various inflammatory mediators which recruit an antifibrinolytic coagulation cascade. Pro-fibrotic cytokines such as tumour necrosis factor alpha (TNF- $\alpha$ ), interleukins (IL) IL- $1 \beta$, transforming growth factor beta (TGF- $\beta$ ), IL-6, IL-8, IL-10, IL-13, chemokines, MCP-1(monocyte chemo attractant protein) and IP-10 (interferon-gamma-inducible protein) are secreted by leukocytes. The activated neutrophils and macrophages remove dead cells thereby eliminating invading organisms. In the consequent phase, ECM, a three-dimensional network of extracellular macromolecules such as collagen, glycoproteins and enzymes, is released by the fibrocytes which proliferate by differentiating into myofibroblasts. Fibroblasts and myofibroblasts resulting from epithelial cells can undergo epithelial mesenchymal transition (EMT). The activated myofibroblasts may promote wound repair in the remodelling and resolution phase; it leads to the restoration of blood vessels and wound contraction which is the regular process occurring in wound healing, but if the same process is dysregulated at any stage in the tissue repair programming process, it leads to the occurrence of fibrosis and lung damage stimulus persists as shown in Fig. 1 [8-13].

\section{Effect of pro-inflammatory and pro-fibrotic mediators}

Various pro-inflammatory and pro-fibrotic mediators play a major role in immune responses. Irritants like asbestos, silica, carbon tetrachloride, bleomycin and uric acid can induce fibrosis in pulmonary epithelial cells which can be sensed in macrophages by the NALP3 inflammasome. The mediators like reactive oxygen species (ROS), chemokines and cytokines produced during this process, which are responsible for inflammation, increase the accumulation and initiation of leukocytes at the sites of wound or injury as shown in Fig. 2 [14]. Cytokine IL-1 $\beta$ allows the initiation of neutrophilexpressing ROS and stimulates the production of profibrotic cytokine TGF- $\beta$, which may additionally lead to epithelial cell damage. The TGF- $\beta$ initiates fibroblast 


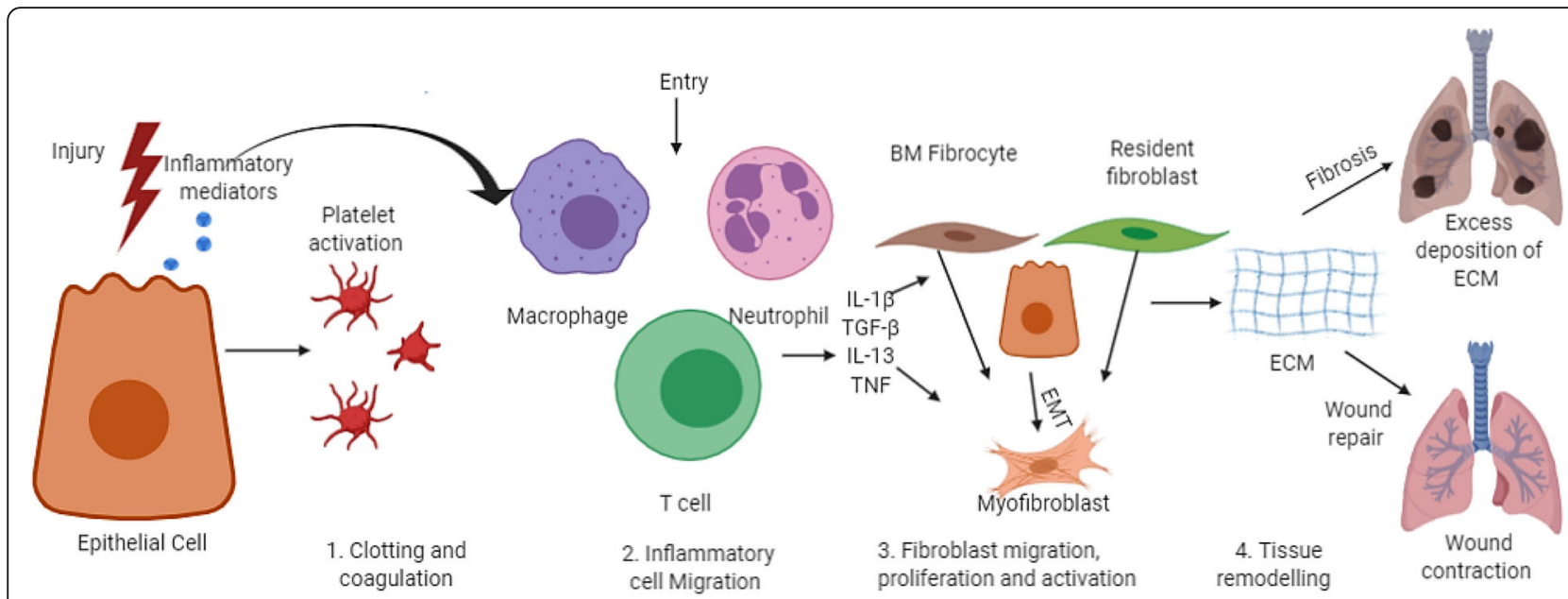

Fig. 1 Mechanism of wound healing [7]

proliferation and activation. This aims epithelial cells towards the formation of ECM by myofibroblasts as shown in Fig. 2 [15]. Hence, TGF- $\beta$ worsens the inflammatory reaction by allowing a subset of pro-inflammatory $\mathrm{T}$ helper cell differentiation to Th17 cells which leads to the production of IL-17 which upon overactivation can also lead to an inappropriate extent of inflammation [16].

\section{Specific subsets of macrophages and T helper cells}

Macrophages are involved in all stages of the fibrotic process, and hence, these are key regulators in the recruitment, proliferation and activation of fibroblasts. Macrophages are classified as M1 and M2 based on differences in their activation, stimuli and amount of proinflammatory cytokines. The compounds produced and their function are listed in Table 1 [17]. Macrophages promote fibrosis by producing chemokines and matrix metalloproteinases (MMP) which degrade ECM and facilitating the enrolment of inflammatory cells at the site of injury [18]. The macrophages release TGF- $\beta 1$ and platelet-derived growth factor (PDGF) which are profibrotic mediators and also involves in the proliferation

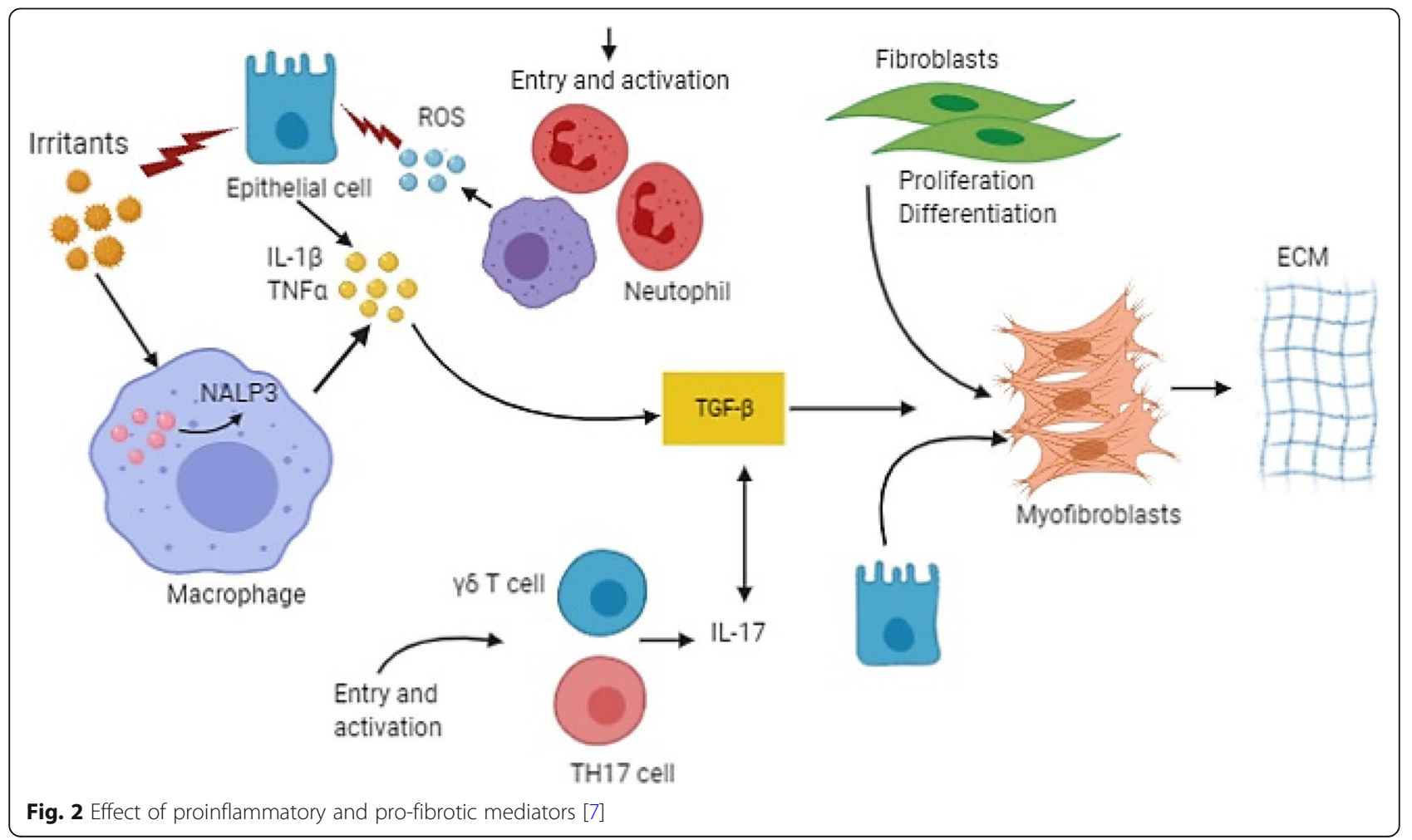


Table 1 Difference between M1 and M2 macrophages

\begin{tabular}{lll}
\hline & M1 macrophages & M2 macrophages \\
\hline Activation & Classically activated & Alternatively activated \\
Th cell involved & Th1 cells & Th2 Cells \\
Subtypes & - & M2a, M2b and M2C \\
Stimuli & IFN- or lipopolysaccharide (LPS) & IL-4, IL-10 or IL-13 \\
Antigen presentation & Yes & No \\
Proinflammatory cytokines & High levels & Low Levels \\
Autophagy & Induced & Decreased \\
Nitric oxide production & Yes & No \\
Phagocytosis & Increases & Decreases \\
Function & Protect against bacteria and viruses & Wound healing and tissue repair build extracellular matrix
\end{tabular}

and activation of myofibroblasts to secrete collagen [1921]. Macrophages can also inhibit fibrosis by releasing mediators that allow apoptosis of myofibroblast and take away cell debris and drive inflammation by digesting, engulfing ECM components and collagen by degrading matrix metallopeptidases in cells which includes neutrophils and myofibroblasts [22]. Epithelial cells when injured release thymic stromal lymphopoietin, IL-25 and IL-33 which enable the progress of pro-fibrotic $\mathrm{T}$ helper type 2 (Th2) responses. Th2 differentiation is promoted by $\mathrm{T}$ cells which release IL-25 and IL-21 [23]. Th2 cytokines also amplify fibrotic responses by initiating chemokines that enable the release of fibrocytes from the bone marrow for collagen secretion [24]. The subsequent myofibroblasts in this mechanism release ECM components as shown in Fig. 3 obtained from Wynn [7]. M2 macrophages which constitute Th2 cytokines further inhibit IL-13 production and myofibroblast differentiation by activating arginase- 1 which also activates antifibrotic feedback mechanisms, whereas Th1 cells produce interferon gamma (IFN- $\gamma$ ), show strong antifibrotic activity by reducing the synthesis of collagen in fibroblasts and stimulate inflammatory M1 macrophages promoting ECM degradation [25]. The entire mechanism of action of macrophages and $\mathrm{T}$ helper cells in fibrosis is shown in Fig. 3.

\section{Intrinsic activation changes in fibroblasts and epithelial cells}

Fibroblasts and epithelial cells promote growth factor independent pulmonary fibrosis, EMT and synthesis of ECM components. In this mechanism, Wnt- $\beta$-catenin

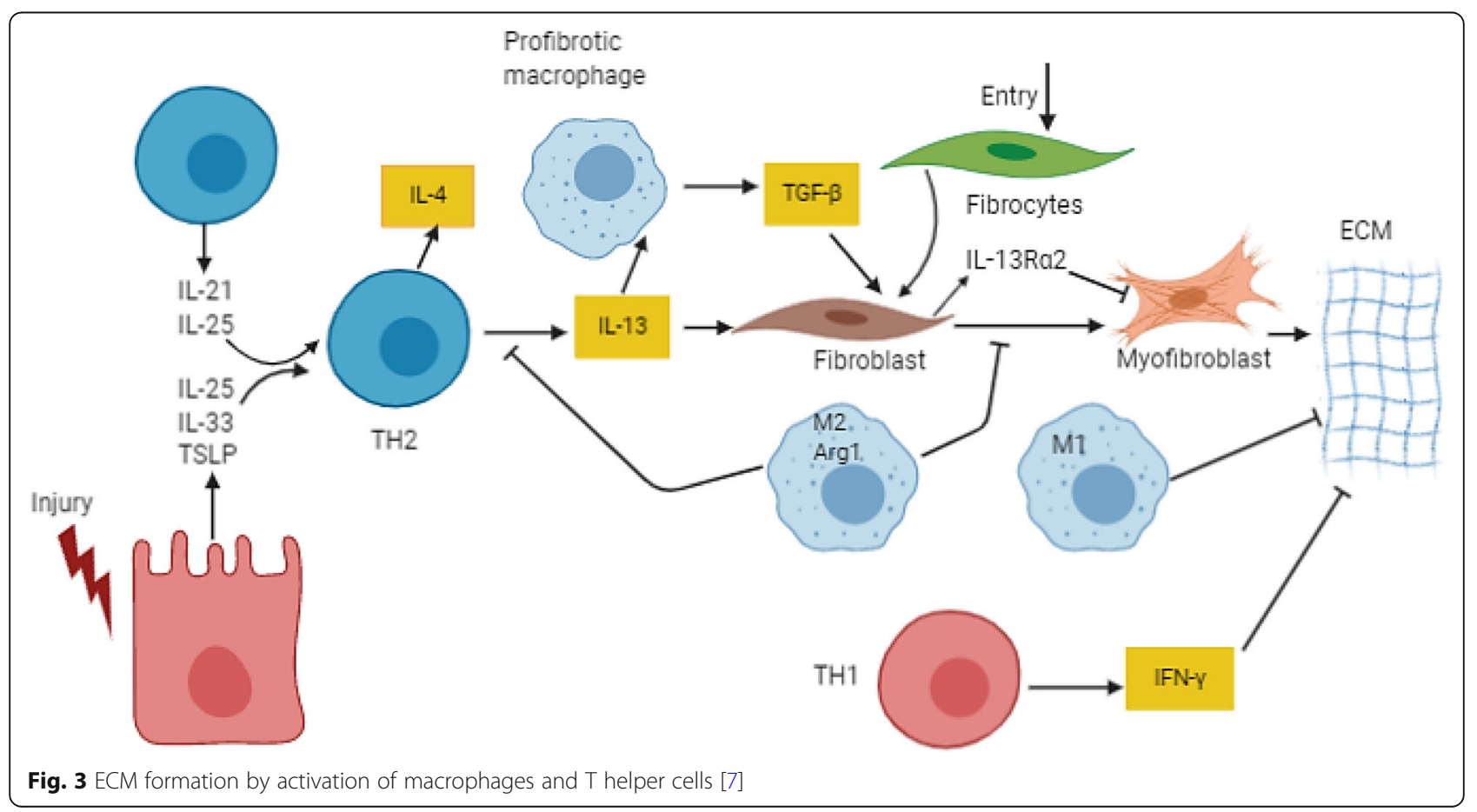


signalling triggered by WNT1-inducible signalling pathway protein 1 (WISP-1) is significantly active in some alveolar type II epithelial cells which are responsible for the regeneration of the alveolar epithelium $[26,27]$. In cardiac fibroblasts, collagen-mediated stimulation of $\beta 1$ integrin upregulates phosphatase and tensin homologue (PTEN) activity and prevents its proliferation. The pathological pattern of $\beta 1$ integrin expression and signalling displayed by fibroblasts can lead to declined PTEN expression and abnormal phosphoinositide 3kinase (PI3K) activation and extreme proliferation [28]. Pro-fibrotic mediators are also responsible for epigenetic changes in fibroblasts leading to fibrosis development where the promoter regions of various genes encoding differentiation factors and autocrine growth factors can be demethylated for controlling heritable and sustained activation. Moreover, methylation and further inactivation of tumour suppressor genes can lead to activation of oncogenes and promotes proliferation of fibroblasts which are independent of growth factors. In this, miRNA may operate alike by obstructing translation or promoting the degradation of tumour suppressor genes [29]. Dysfunction of any of these mechanisms mentioned above can lead to the formation of fibrosis. Some plant extracts and their bioactive compounds have the capability to overcome the fibrotic process in any stage of the mechanism and help to prevent the formation of fibrosis.

\section{Particles and chemical compounds which are fibrinogenic to lungs}

Various compounds which upon interaction induce pulmonary fibrosis are listed below. These are also used in particular to induce pulmonary fibrosis during experimental studies. The most commonly used compounds are bleomycin and carbon tetrachloride.

Bleomycin (BLM) is a glycopeptide antibiotic commonly used to induce pulmonary fibrosis in rats for experimental studies [30]. It was first isolated from Streptomyces verticillatus [31, 32]. Crystalline silica dusts upon pulmonary exposure in humans cause silicosis which is characterized by the occurrence of inflammation and fibrosis in lungs, weakening of lung functions and premature death [33]. Paraquat (N, N-dimethyl-4, 4'-bipyridinium dichloride) is a herbicide and is a potent toxin to the lungs which will cause intra-alveolar fibrosis in epithelial cells and damage lung architecture [34]. Amioahrone, a cardiac anti arrhythmic agent, is linked with the development of interstitial pulmonary fibrosis upon prolonged therapy [35]. Cyclophosphamide is an alkylating agent used as a drug which when administrated causes interstitial lung disease, which leads to pulmonary fibrosis and lung abrasion [36]. Periostin is a matrix cellular protein that shows a distinctive role like chemokine inducer in the recruitment of macrophages and neutrophils which play a key role in causing pulmonary fibrosis in bleomycin-administered mice [37]. Carbon tetrachloride $\left(\mathrm{CCl}_{4}\right)$ had been used to induce pulmonary fibrosis in rats with increased volume densities of type III and type IV collagen, and laminin [38, 39]. Carbon tetrachloride is commonly used to induce liver fibrosis [40]. Aerosol particle polyhexamethylene guanidine phosphate induces pulmonary inflammatory and fibrotic response although its mechanism to induce fibrosis was unclear [41]. Irradiation can also induce pulmonary fibrosis [42].

\section{Diagnosis of pulmonary fibrosis}

Pulmonary fibrosis is commonly diagnosed by chest Xray [43], computerized tomography (CT) scan [44], echocardiogram [45, 46], pulmonary function testing [47, 48], pulse oximetry [49], exercise stress test [50], arterial blood gas test [51], bronchoscopy [52] and surgical biopsy [53].

\section{Treatment for pulmonary fibrosis with synthetic drugs}

Pulmonary fibrosis was currently treated with corticosteroids, endothelin receptor antagonists, tyrosine kinase inhibitors glucocorticoids, colchicine, $\gamma$-interferon, antioxidants, cyclophosphamides and cyclosporin A which are listed in Table 2. These drugs, even though are therapeutic, have high side effects. The long-term effect and safety of the new drugs like pirfenidone and nintedanib remain ambiguous. Therefore, it is essential to screen drugs with progressive therapeutic effects to treat pulmonary fibrosis $[69,70]$. IPF in patients is frequently identified late in the course of the disease and many die before receiving a transplant. Therefore, initial diagnosis is necessary for evaluation and transplantation.

\section{Techniques and procedures used in experimental studies to determine the extent and cure for fibrosis}

Before concluding on the activities of any drug which is synthetic or natural in origin, experimental studies are necessary and a must. The various techniques used in experimental studies on pulmonary fibrosis are:

Microscopy techniques are used to count differential alveolar cells by using the May-Grunwald-Giemsa stain. Differential cell count from broncho alveolar lavage fluid provides information regarding the total cell count and percentage of lymphocytes, neutrophils, eosinophils and macrophages. Biochemical analyses of proteins, hydroxyproline are needed to be assessed in order to measure the amount of collagen deposited in the lung tissue. Myeloperoxidase and malondialdehyde levels need to be measured. Transcription of fibrotic genes is done by 
Table 2 Drug designed to treat idiopathic pulmonary fibrosis

\begin{tabular}{llll}
\hline S. no. & Type/effect & Drug used & Reference \\
\hline 1 & Corticosteroids & Cochrane & {$[54]$} \\
2 & Immunomodulator agent & Azathioprine & {$[55]$} \\
3 & Cytokine inhibitor & Etanercept & {$[56]$} \\
4 & Cytokine & Interferon- & {$[57]$} \\
5 & Phosphodiesterase inhibitor & Sildenafil & {$[58]$} \\
6 & Endothelin receptor antagonist & Bosentan, macitentan and ambrisentan & {$[59-61]$} \\
7 & Anti-oxidant & N-Acetylcysteine & {$[62]$} \\
8 & Anticoagulant & Warfarin or heparin & {$[63]$} \\
10 & Tyrosine kinase inhibitor & Imatinib & {$[64]$} \\
11 & Tyrosine kinase inhibitor & Nintedanib & {$[65]$} \\
12 & anti-inflammatory, anti-oxidant and anti-fibrotic & Pirfenidone & {$[66]$} \\
13 & Immunosuppressant & Cyclosporine A & {$[67]$} \\
\hline
\end{tabular}

isolating RNA and reverse transcribed using RT PCR with primers against TGF- $\beta 1$ which is responsible for inducing extreme production and deposition of collagen, procollagen I $\alpha$, tissue inhibitor of metalloproteinase (TIMP-1) and matrix metallopeptidase 9 (MMP-9). These are gelatinases, matrix metalloproteinases and tissue inhibitors of metalloproteinases. Antioxidant assays are carried out to determine the levels of catalase, superoxide dismutase, peroxidase, nitric oxide, glutathione reductase, glutathione peroxidase, glutathione-Stransferase, $\gamma$-glutamyl transpeptidase and quinone reductase. Along with cell viability, IL-6, TNF- $\alpha$, MCP-1 and endothelin-1 levels need to be determined.

\section{Role of plants and their bioactive compounds that can be used to treat pulmonary fibrosis}

The name of the plant, its active compound and the experimental model that is used in treating pulmonary fibrosis are listed in Table 3 . The mode of activity of plants and their bioactive compounds are illustrated in Fig. 4.

\section{Nelumbo nucifera}

Neferine, which is a bisbenzylisoquinline alkaloid, is extracted from the embryo seed of the plant Nelumbo nucifera gaertn and it attenuates bleomycin-induced pulmonary fibrosis. Neferine was found to be more effective in reversing the bleomycin-triggered activities such as reduction of superoxide dismutase (SOD) in the lungs, rise in myeloperoxidase (MPO) and malondialdehyde (MDA) levels. Neferine additionally relieved the bleomycin-induced rise of pro-inflammatory cytokines like endothelin-1, TNF- $\alpha$ and IL- 6 in tissue or plasma. Neferine also obstructed the bleomycininduced rise of TGF- $\beta 1$ and nuclear factor kappa- light-chain-enhancer of activated B cells (NF- $\mathrm{kB}$ ) in total protein extracts and nuclear extracts respectively [71].

\section{Arenaria kansuensis}

The $\beta$-carboline alkaloids present in ethylacetate extract of Arenaria kansuensis showed an antifibrogenic effect by suppressing inflammatory cytokines TNF- $\alpha$, IL-1 $\beta$, MCP- 1 and IL- 6 . The $\beta$-carboline alkaloids of this plant inhibited the initial inflammation by inhibiting NF- $\mathrm{kB} / \mathrm{p} 65$ pathway and backing the process of EMT. The expression of indicators vimentin, alphasmooth muscle actin ( $\alpha$-SMA) and E-cadherin of EMT was considerably amended after the administration of different $\beta$-carboline alkaloids [72, 73]. The expression of TGF- $\beta 1, \alpha$-SMA, E-cadherin and collagen deposition was significantly raised after the administration of this plant extract. All the twelve alkaloids isolated from this plant, monoacetylarenarine B, 3-hydroxymethyl- $\beta$-carboline, arenarine A, glusodichotomine $\mathrm{AK}$, cordysinin $\mathrm{C}$, arenarine $\mathrm{D}, 7$-methoxy1-oxo-1,2,3,4-tetrahydro- $\beta$-carboline, 3 -hydroxy- $\beta$-carboline, $\beta$-carboline1-carboxylic acid, cordysinin $E$, $1,2,3,4$-tetrahydro-1,3,4-trioxo- $\beta$-carboline and arenarine $B$, are together used to treat IPF and found to reduce fibrotic activities [73].

\section{Mahonia aquifolium}

The bark of Mahonia aquifolium contains a lot of isoquinoline alkaloids like berberine, berbamine, palmatine, magnoflorine and jatrorrhizine [74, 75]. The action of isoquinoline alkaloids and their action on various factors leading to pulmonary fibrosis are dealt with later in this article. 


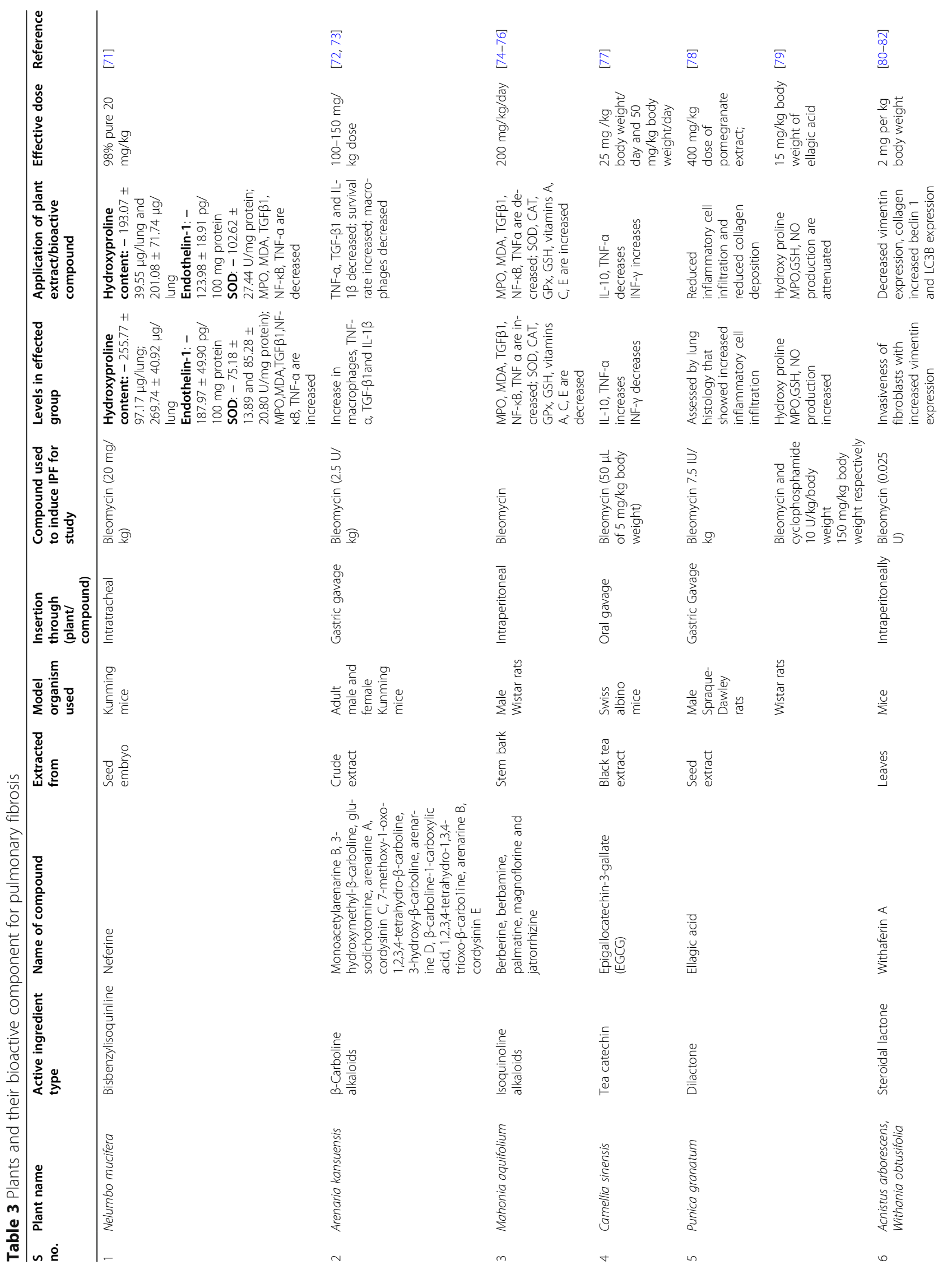




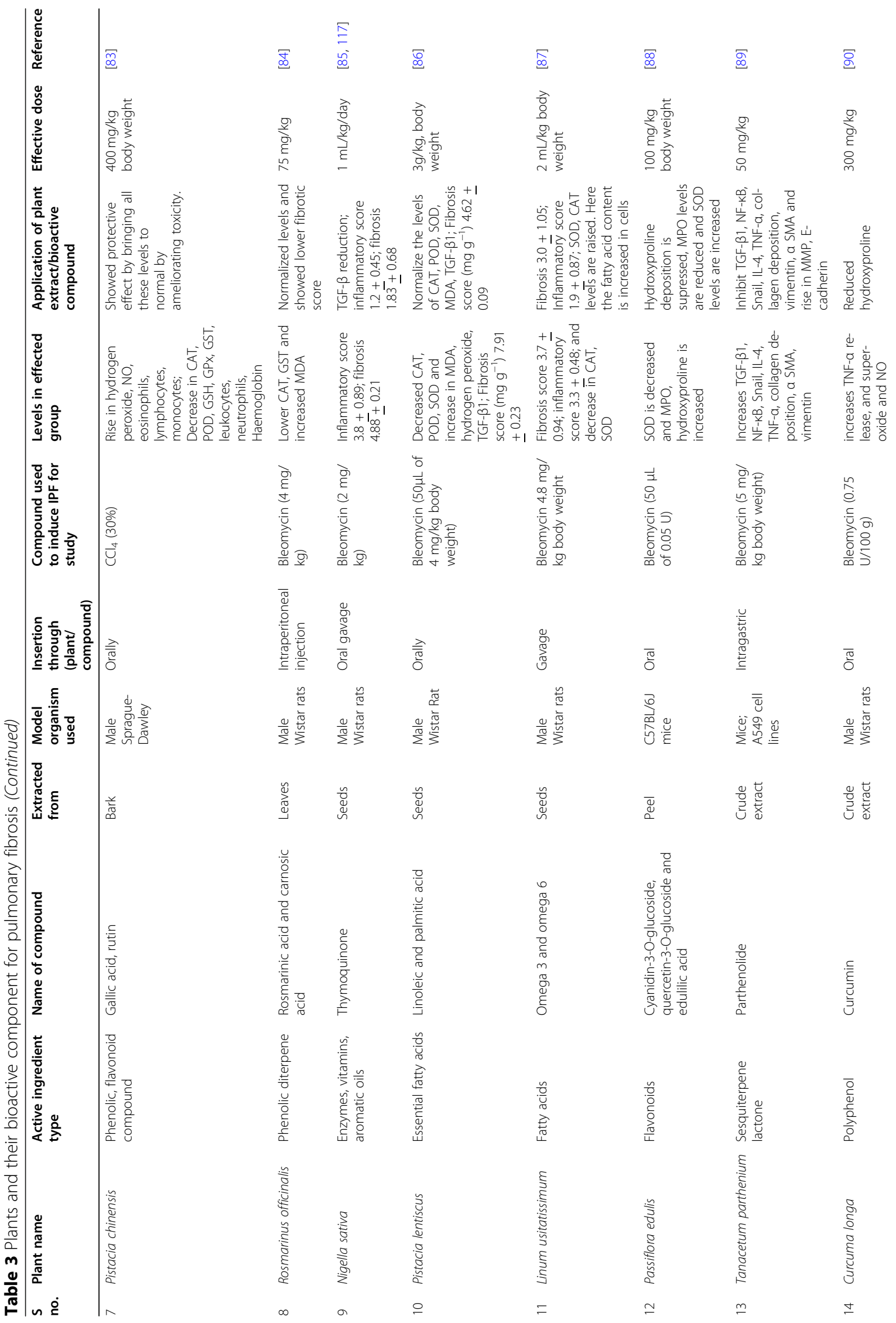




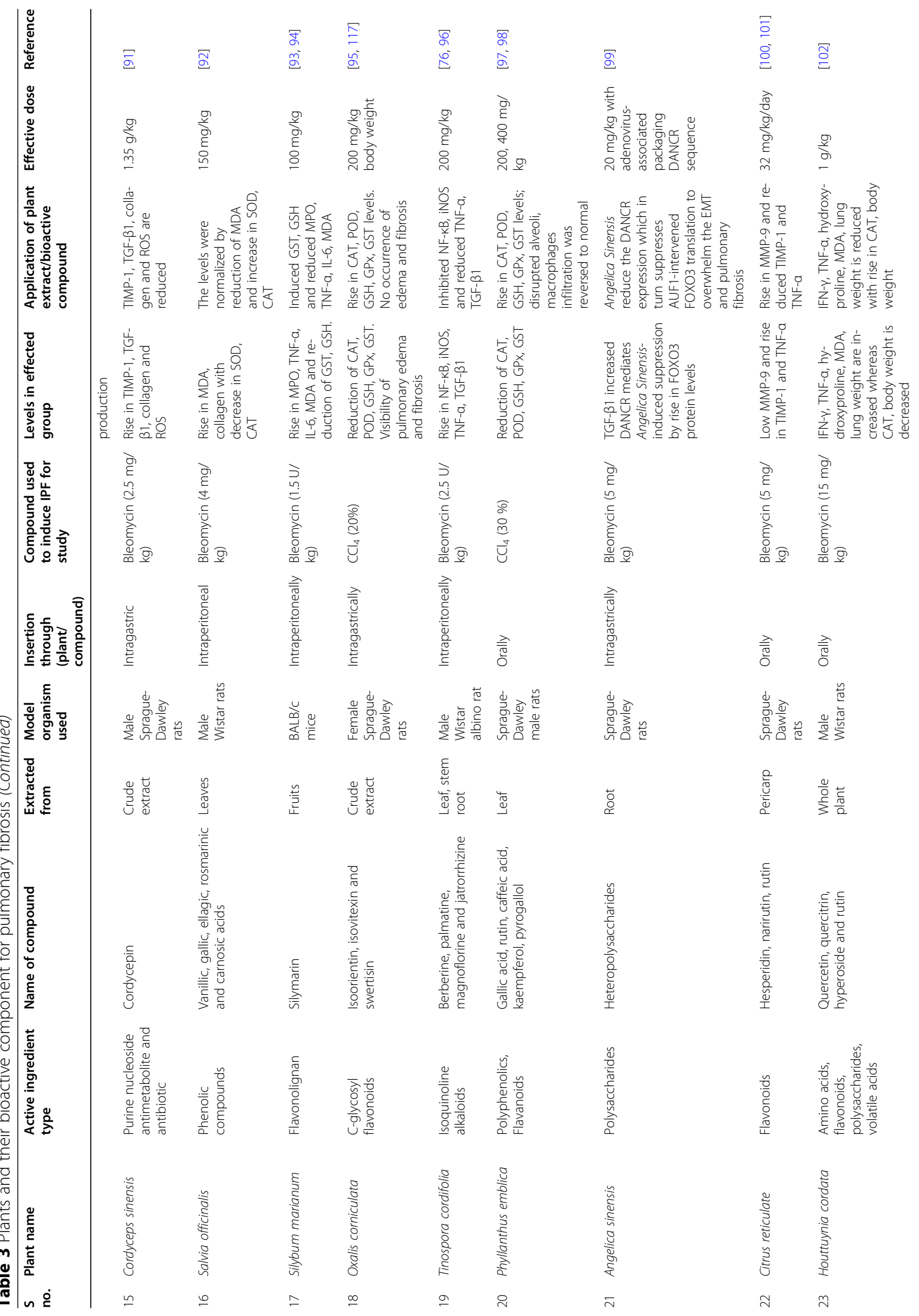




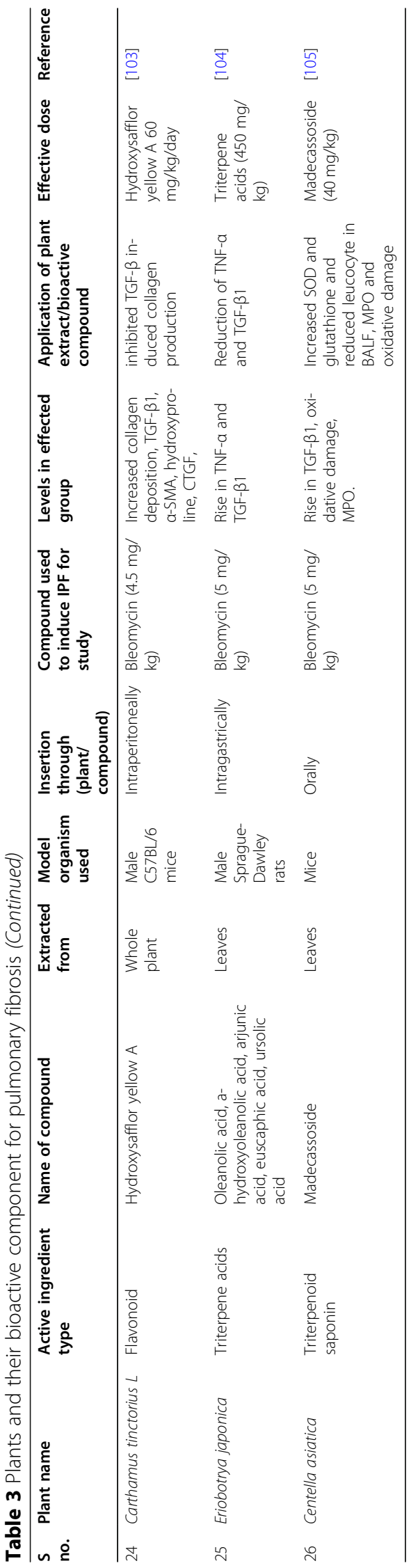




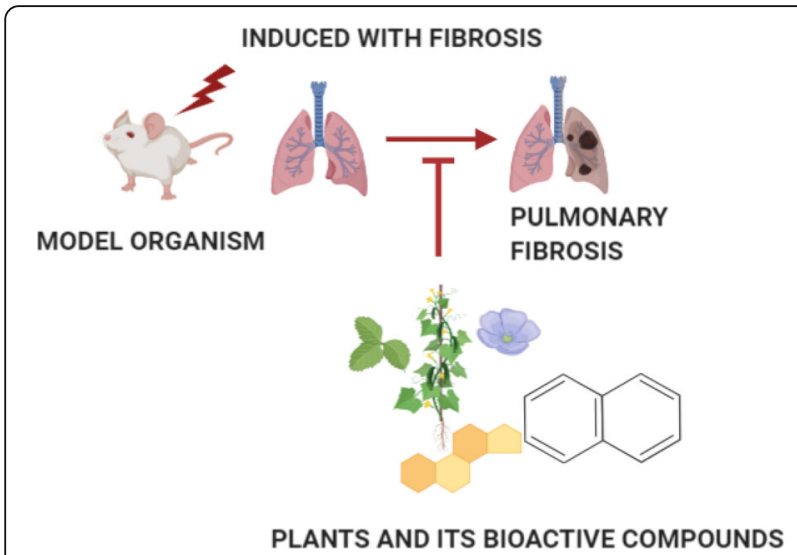

Fig. 4 Effect of plants and bioactive compounds in treating IPF

\section{Camellia sinensis}

The decreased $\alpha$-SMA expression in bleomycin-induced mice and downregulated TGF- $\beta$ expression and upregulated expression of IFN- $\gamma$ in experimental pulmonary fibrosis showed that black tea extract (Camellia sinensis) can be effective for treating pulmonary fibrosis [77]. Epigallocatechin-3-gallate (EGCG), a bioactive compound isolated from green tea extract, prevents pulmonary fibrosis induced by irradiation and provides a strong, persistent antioxidant capacity by preventing the synthesis and emission of ROS/RNS free radicals which is responsible for oxidative damage in parenchymal cells; the anti-inflammatory capacity is enhanced by suppressing the expression of key inflammatory cytokines TNF- $\alpha$, TGF- $\beta 1$, IL- 6 and IL-10, and the anti-proliferative activity is also enhanced to protect against irradiationinduced pulmonary fibrosis in rats. EGCG inhibits myofibroblast proliferation and (AE2) anion exchange protein 2-cell dysplasia by suppressing TGF- $\beta 1$ [106]. Epigallocatechin-3-gallate is a tea catechin [107, 108]. EGCG binds directly to the proinflammatory chemokines CXCL9, CXCL10 and CXCL11 and intensely inhibits their chemotactic capabilities. EGCG also reduced Th1 cell and other inflammatory cell recruitment and inflammatory response in airways and lung tissues [109].

\section{Nuts and fruits}

Ellagic acid is the dilactone of hexahydroxydiphenic acid present in many nuts and fruits such as black raspberries, pomegranates, strawberries, raspberries, almonds and walnuts attenuates cyclophosphamide and bleomycin-induced pulmonary toxicity. Ellagic acid a polyphenolic compound when given orally showed a significant decrease in hydroxyproline, lipid peroxidation, nitric oxide production, protein carbonyl level, myeloperoxidase activity and increase in glutathione levels and antioxidant levels [78].

\section{Punica granatum}

The Punica granatum (pomegranate) seed extract has been shown to prevent pulmonary fibrosis induced by bleomycin in rats. Low inflammatory cell infiltration and reduced collagen deposition have been observed when compared with that of bleomycin-induced rats. Overall, the study showed the antioxidant effects of the pomegranate seed extract in a dose-dependent manner and was also found to have the best antioxidant effect when given in high dosages [79].

\section{Pistacia chinensis}

Pistacia chinensis bark (PCEB) is used as a potent ameliorator for carbon tetrachloride $\left(\mathrm{CCl}_{4}\right)$-induced lung toxicity and found to possess antioxidant activity by free radical-quenching components. The major constituents of the plant are the phenolic compound gallic acid and the flavonoid compound rutin. The other compounds detected by thin-layer chromatography are ascorbic acid, catechin, kaempferol and tannin. Toxicity of $\mathrm{CCl}_{4}$ was ameliorated with PCEB treatment which significantly inhibited the increase of hydrogen peroxide, thiobarbituric acid-reactive substances, nitrite and protein content. The activity levels of various antioxidant enzymes like superoxide dismutase, peroxidase, catalase, glutathione peroxidase, glutathione-S-transferase, $\gamma$-glutamyl transpeptidase, glutathione reductase and quinone reductase are restored in both thyroid and lung tissues in rats treated with $\mathrm{CCl}_{4}$. It also increased the total leukocyte count and neutrophil and haemoglobin levels. In addition, it decreased the number of lymphocytes, monocytes and eosinophils. These actions are reliant on dosage. All the results presented show that this plant can be used in the treatment of pulmonary fibrosis [83].

\section{Rosmarinus officinalis $\mathrm{L}$.}

Rosmarinus officinalis L. (Lamiaceae) leaves extract which contains a high amount of carnosic acid has a protective effect against bleomycin-induced oxidative stress and lung fibrosis. The effect of these leaf extracts includes restored catalytic activity of the lung treated with bleomycin. It has antioxidant activity. Lipid peroxidation was assessed by malondialdehyde which is produced due to oxidative breakdown of lipids. Polyunsaturated fatty acids were deduced when compared with that of the bleomycin group. Glutathione-S-transferase which is essential for stimulation of antioxidant enzymes, ROS detoxification and thiol group levels in the lungs were significantly increased by rosemary extract, whereas in the bleomycin group, they are decreased giving us hope for using this plant for treating pulmonary fibrosis [84]. 


\section{Nigella sativa}

Nigella sativa (black cumin), which is used as a traditional Tunisian herbal medicine, in which oil extracted from seeds denoted by NSO, attenuates bleomycininduced pulmonary fibrosis. Immunohistochemical studies determined that this extract reduced the concentration of TGF- $\beta$ in lung fibrocytes suggesting NSO can be used as an effective anti-inflammatory and antifibrotic agent. Carnosine present in this extract has been shown to reduce lipoxidation products and inhibit protein crosslinking. High levels of histidine during the NSO treatment could lead to the synthesis of carnosine, which promotes glycation of proteins and oxidative damage by its anti-inflammatory and antioxidant properties. Histological analysis determined that NSO-treated ones showed a rise in choline which was accompanied by extracellular matrix formation and structural disruption of the cell membrane in the alveoli [85].

\section{Pistacia lentiscus}

Pistacia lentiscus oil containing linoleic and palmitic acid as major constituents showed a protective effect against bleomycin-induced lung fibrosis by reversing all bleomycin-induced oxidative stress parameters like TGF- $\beta$, lipid peroxidation, superoxide dismutase and catalase disturbances by its antioxidant properties. The polyunsaturated fatty acids present in the extract acts as a major compound for exhibiting rich antioxidant properties [86].

\section{Linum usitatissimum $\mathrm{L}$.}

The Linum usitatissimum L. herb is also known as flaxseed or linseed. Bleomycin administration followed by flaxseed oil treatment decreased the bleomycin-induced increased level of glucose, proline and glyceride rates in bronchoalveolar lavage fluid (BALF). The histological results showed a decline in inflammatory index and fibrosis score. This seed oil which constitutes linoleic, arachidonic, dihomo- $\gamma$-linoleic and docosapentaenoic acids significantly decreased the levels of thiobarbitunic acid reactive substance in the rat lungs and raised levels of superoxide dismutase, catalase and fatty acids stimulating anti-inflammatory reactions in erythrocytes which showed that treatment with this oil significantly attenuated pulmonary damage induced by bleomycin [87].

\section{Passiflora edulis}

Passiflora edulis a purple passion fruit contains three major components quercetin-3-O-glucoside, cyanidin-3$\mathrm{O}$-glucoside and edulilic acid. Peel extract of this passion fruit attenuates bleomycin-induced pulmonary fibrosis. It has anti-inflammatory activity as indicated by a decrease in neutrophil accumulation and MPO activity in BALF and lung tissue respectively. Pre-treatment with this plant extract significantly restored bleomycininduced reduction of superoxide dismutase activity and myeloperoxidase and increased hydroxyproline and collagen formation to normal showing its curative effects in treating pulmonary fibrosis [88].

\section{Tanacetum parthenium}

Parthenolide is a sesquiterpene lactone that can be extracted from feverfew (Tanacetum parthenium) shoots. Parthenolide via the NF- $\mathrm{kB} /$ Snail signalling pathway had been shown to attenuate bleomycin-induced pulmonary fibrosis. Parthenolide in a dose-dependent manner abridged the viability of lung fibroblasts. Wound healing assay determined its influence on the cellular migration of lung fibroblasts. Parthenolide-treated cells exhibited a delay in wound closure and inhibits the expression of transcription factors. Reduced inspiratory and expiratory resistance with a rise in dynamic compliance compared to mice treated with bleomycin suggested that parthenolide attenuates bleomycin-induced pulmonary fibrosis. The inflammatory cytokines like TNF- $\alpha$, TGF- $\beta$ and IL4 decreased significantly in mice treated with parthenolide in a dose-dependent manner compared to untreated mice which showed that parthenolide inhibits the inflammatory responses which lead to pulmonary fibrosis. The parthenolide-treated groups exhibited a substantial reduction in collagen deposition. Parthenolide increased matrix metalloproteinase MMP1 [110] levels and decreased Col-1 collagenase [89]. Parthenolide inhibits ІкB kinase which is an enzyme complex that is involved in proliferating the cellular response to inflammation; $\mathrm{NFKB}_{\mathrm{K}}$ activation presents a vital part in regulating the immune response during infection in cystic fibrosis cells and mice [111].

\section{Curcuma longa}

Curcumin (diferuloylmethane), a polyphenol, is the major active component of turmeric which is a rhizomatous herbaceous perennial plant Curcuma longa that has antioxidant, anti-cancer, anti-inflammatory properties $[112,113]$. Curcumin has the ability to suppress pulmonary fibrosis induced by bleomycin. Bleomycin causes a significant rise in total cell numbers, protein, angiotensin-converting enzyme and alkaline phosphatase activities in BALF and also increases TNF- $\alpha$ release by alveolar macrophages. Bleomycin also showed an increase in superoxide and nitric oxide in a cell culture medium and an increase in the lung hydroxyproline content. All the above-mentioned effects of bleomycin were reduced by curcumin [90]. Moreover, it stops proliferation of lung fibroblasts, myofibroblast differentiation and collagen secretion by IPF fibroblasts. Hence, these studies affirm that curcumin can be used in IPF treatment [114]. 


\section{Cordyceps sinensis}

Cordyceps sinensis is a fungal species used in Chinese medicine. It reduces TGF- $\beta 1$-dependent EMT by the presence of a soluble polysaccharide component in its crude extract [115]. Cordycepin (3'-deoxyadenosin), which is present in Cordyceps sinensis extract, is an adenosine analogue and the active ingredient, responsible for the reverse back mechanism of EMT $[91,116]$.

\section{Salvia officinalis}

Salvia officinalis is a well-reputed medicinal plant that consists of good amounts of phenolic compounds. Leaf extract of this plant was found to attenuate bleomycininduced pulmonary fibrosis and oxidative stress in rats. The reduced catalase activity in bleomycin-induced rats was restored when compared with that of the control group with this treatment and also reported that it showed an effect on superoxide dismutase, lipid peroxidation, oxidative stress and fibrotic score which was decreased when given in specific content [92].

\section{Silybum marianum L.}

Silymarin extracted from Silybum marianum L., commonly known as milk thistle belongs to the family Asteraceae, alleviates bleomycin-induced lipid peroxidation and pulmonary toxicity. Silymarin induction to bleomycin-administered mice resulted in a significant reduction in thiobarbituric acid reacting substances, IL-6, TNF- $\alpha$, myeloperoxidase activity. This treatment leads to a substantial rise in catalase and pulmonary glutathione, all favouring in reducing the impact of pulmonary fibrosis [93].

\section{Oxalis corniculata}

Oxalis corniculata, also known as creeping wood belongs to the family Oxalidaceae. It is used in the amelioration of $\mathrm{CCl}_{4}$ induced pulmonary toxicity, and so, it can also be used to treat pulmonary fibrosis. This extract dose dependently prevented the alterations caused by carbon tetrachloride like thickening of alveolar walls, rupturing of the lung alveolar septa and causing damage to cells with the subsequent collapse of blood vessels due to the build up of degenerated blood cells [117]. It is a rich source of C-glycosyl flavones which are isovitexin, swertisin and isoorientin [95].

\section{Phyllanthus emblica}

Phyllanthus emblica leaf extract, due to the presence of polyphenolics and other active components, may have an important role in repairing the damaged lungs instigated with $\mathrm{CCl}_{4}$ that induced production of free radicals and toxicity in the lungs in rats. The polyphenolic constituents present in methanolic leaf extract are gallic acid, kaempferol, caffeic acid and rutin. It constitutes pyrogallol as an antiproliferative compound [97]. Methanolic extract of the plant (dried) solid extract which constitutes total flavonoid and phenolic content is tested for its antioxidant potential by 1-diphenyl-2-picryl-hydrazyl (DPPH) radical scavenging activity, nitric oxide scavenging assay and lipid peroxidation assay. Sprague-Dawley male rats were taken to test the effect of plant extract on pulmonary fibrosis and stated that this has a significant role in repairing pulmonary fibrosis [98].

\section{Angelica sinensis}

Angelica Sinensis root extract which constitutes polysaccharides when given intragastrically to Sprague-Dawley rats that were previously treated with bleomycin to induce pulmonary fibrosis showed suppressed fibrogenesis and EMT [99].

\section{Citrus reticulate}

Citrus reticulate alkaline extract of pericarp given orally to bleomycin-induced Sprague-Dawley male rats had shown a preventive effect against pulmonary fibrosis by upregulation of MMP-9 expression and inhibition of the expressions of TNF- $\alpha$ and TIMP-1. Human embryonic lung fibroblasts are used for evaluating the inhibitory effect in vitro [100]. Flavanone glycosides namely hesperidin, narirutin and rutin are present in relatively large amounts in peel and rutin has antioxidant capabilities [101].

\section{Houttuynia cordata}

Houttuynia cordata, a herbaceous perennial plant, exhibits antiviral, anti-inflammatory, immunologic, antibacterial, antimutagenic, anticancer and antioxidative pharmaceutical activities. Various bioactive compounds present include thirteen amino acids of which six are essential amino acids, flavonoids, volatile oils and watersoluble polysaccharides [118]. The aqueous extract of this plant taken orally can have a protective effect on bleomycin-induced pulmonary fibrosis. IFN- $\gamma$ and TNF$\alpha$ which are increased in bleomycin-induced models were significantly suppressed after treatment with this plant extract [102].

\section{Carthamus tinctorius L.}

Carthamus tinctorius L. is a bushy herbaceous annual or winter annual widely known as safflower or false saffron is used as a traditional medicine for various health conditions [119]. Hydroxysafflor yellow A (HSYA) is an active component extracted from aqueous extract of this plant. In mice, it had been known to attenuate bleomycin-induced pulmonary fibrosis. HSYA reduced the lung consolidation area, collagen deposition, TGF$\beta 1, \alpha$-SMA and collagen I mRNA levels. It repressed the increase of Smad3 phosphorylation, expression of $\alpha$ - 
SMA and expression of collagen I mRNA brought by TGF- $\beta 1$ that facilitate EMT [103].

\section{Eriobotrya japonica}

Eriobotrya japonica, a loquat, is a large evergreen shrub which contains triterpene acids that can be used as a prophylactic for treating pulmonary fibrosis due to its antifibrosis effect. Triterpene acids present constitute oleanolic acid, euscaphic acid, arjunic acid and ursolic acid. The antifibrosis effect of these triterpene acids of loquat was determined in bleomycin-treated rats. These triterpene acids of loquat showed a reduction of collagen content in the lung parenchyma and decreased the number of cells. These decreased TNF- $\alpha$ mRNA and TGF- $\beta 1$ expression in the model group suggest that these could downregulate TNF- $\alpha$ mRNA expression and TGF- $\beta 1$ [104].

\section{Centella asiatica}

Centella asiatica herbs contain madecassoside, a triterpenoid saponin which ameliorates bleomycin-induced pulmonary fibrosis in mice by reducing the deposition of collagen. It decreased TGF $\beta 1$ and $\alpha$-smooth muscleacting expressions and also inhibited the Smad2 and Smad3 phosphorylations in the lung tissues. It attenuated oxidative damage and inflammation by reducing total leukocytes in the BALF and also reducing malondialdehyde level, myeloperoxidase activity and increasing SOD activity and glutathione level in lung tissues. Thus, madecassoside ameliorates pulmonary fibrosis by preventing extracellular matrix deposition, which might be achieved mainly through oxidative stress, attenuating inflammation and resultant overexpression of TGF $\beta 1$ [105]. In this way, plants can be used in treating IPF. The therapeutic effect of plants on various factors and pathways leading to IPF is tabulated in Table 4.

\section{Isoquinoline alkaloids}

Isoquinoline alkaloids are tyrosine-derived plant alkaloids with an isoquinoline skeleton. Among them, benzylisoquinoline alkaloids form an important group with potent pharmacological activity. Biosynthesis of isoquinoline alkaloids proceeds via decarboxylation of tyrosine or DOPA to yield dopamine, which together with an aldehyde (4-hydroxyphenylacetaldehyde) derived from tyrosine convert to reticuline, an important precursor of various benzylisoquinoline alkaloids. Among various isoquinoline alkaloids like berberine, magnoflorine, tetrahydropalmatine and jatrorrhizine are synthesized in plants belonging to the families Papaveraceae, Berberidaceae, Fumariaceae, Menispermaceae, Ranunculaceae and Rutaceae, and Annonaceacan plays an important role to treat pulmonary fibrosis by acting on specific inflammatory factors and by acting on various metabolic processes that commonly leads to pulmonary fibrosis.

\section{Berberine}

Berberine is an isoquinone plant alkaloid, which is a quaternary ammonium salt formed from the protoberberine group. Benzyl isoquinoline alkaloids found in plants are known for their broad range of pharmacological activities to treat multiple diseases [120]. Berberine can be used to treat idiopathic pulmonary fibrosis. Administration of berberine significantly improved bleomycin-induced histological alterations by decreasing the inflammatory cell infiltrate in bronchoalveolar lavage fluid (BALF). Berberine had significantly blocked the accumulation of collagen with an equivalent decline in the level of hydroxyproline. Bleomycin induced activation of nuclear factor kappa $\beta$ (NF- $\beta$ ) which controls the expression of IL- $1 \beta$ and TNF- $\alpha$ gene in monocytes and macrophages is inhibited by berberine. It repressed its downstream target inducible nitric oxide synthase (iNOS) [121]. Outstandingly, berberine showed target attenuation of key pro-fibrotic mediator, TNF- $\alpha$ and TGF$\beta 1$ against bleomycin-induced fibrosis by activating Nrf2 and suppressing fibrotic events mediated by NF- $\beta$ and TGF- $\beta 1$ [76]. Various signals are carried by serine/threonine kinase receptors through the cell surface towards the intracellular mediators by the TGF- $\beta$ superfamily member known as Smads which upon initiation causes their translocation from the cytoplasm towards the

Table 4 The therapeutic effect of plants on various factors and pathways leading to IPF

\begin{tabular}{|c|c|c|c|}
\hline \multirow{2}{*}{$\begin{array}{l}\text { S. } \\
\text { no. }\end{array}$} & \multirow{2}{*}{$\begin{array}{l}\text { Pathway responsible for } \\
\text { IPF }\end{array}$} & \multicolumn{2}{|c|}{ Compounds responsible and effect of plant extracts } \\
\hline & & Increase & Decrease \\
\hline 1. & Oxidative stress regulations & GSH, CAT, SOD, GPX & ROS, MDA, NOS, NO, MPO \\
\hline 2. & Autophagy inhibition & & LC3A, beclin \\
\hline 3. & Signalling pathway regulation & Nrf2-Keapl & 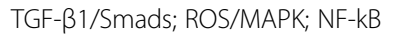 \\
\hline 4. & EMT reversion & E-Cadherin & Vimentin, a-SMA, Snail \\
\hline 5. & Inflammation regulation & & TNF-a, IL-1 $\beta, 4,6,8,10,13,17,18$ \\
\hline 6. & Fibrotic regulation & & MMP-2,9; collagen, Smad 2/3; TIMP \\
\hline 7. & Other roles & $\mathrm{IFN}-\gamma$ & PDGF, hydroxyproline \\
\hline
\end{tabular}


nucleus to control gene expression [122, 123]. NonSmad and Smad signalling cascades, mediated by TGF$\beta 1$, act as chief players in accelerating pulmonary fibrosis of which berberine eased the raised expression of fibrotic markers, fibronectin, $\alpha$-smooth muscle actin ( $\alpha$-SMA) and collagens I and III and reversed structural changes induced by bleomycin in the lungs and inhibited the bleomycin-induced increase in p-Smad 2/3 and enriched Smad 7 expression. It obstructed the activation of focal adhesion kinase (FAK) and phosphatidylinositol 3kinases (PI3K/Akt). Protein kinase B known as Akt is a serine/threonine-specific protein kinase that plays a crucial role in cell proliferation, apoptosis, transcription, glucose metabolism and cell migration. Berberine targeted inhibition of dysregulated Smad and FAKdependent PI3K/Akt mTOR signalling axis (mammalian target of rapamycin) reduced the fibrotic effects of bleomycin [124]. Berberine had been shown to act against dysregulation induced by bleomycin with a successive rise in phosphatase and tensin homologue (PTEN) expression. PTEN through the action of its protein product phosphatase acts as a tumour suppressor gene where it is involved in the regulation of the cell cycle by preventing cells from rapid growth and division. It plays a crucial role in cell cycle arrest, apoptosis and possibly cell migration [125]. Epithelial PTEN controls fibrosis and acute lung injury by regulating the integrity of alveolar epithelial cells. Inactivation of PTEN exacerbates the TGF $\beta 1$-induced interruption of tight junctions in epithelial cells of the lungs [126, 127]. Berberine initiating autophagy is supported by the rise in Beclin-1 and LC3-II levels with enriched autophagosome formation. In general, LC3-II and Beclin-1 expressions in two major types of lung cancer which are adenocarcinoma and squamous cell carcinoma, in which both mRNA and protein levels of LC3-II and Beclin-1 which are autophagy-related genes were considerably reduced in lung cancer tissues suggesting autophagy may be involved in the pathogenesis of lung cancer [128]. Berberine through downregulation of matrix metalloproteinases (MMP) will inhibit pulmonary metastasis in B16F-10 melanoma cells. B16-F10 cells are used to develop a primary tumour model [129]. MMPs produced by metastatic cells have a main role in the degradation of the basement membrane, which is crucial for the invasiveness of metastatic cells. Berberine significantly suppressed tumour nodule formation induced by B16F-10 melanoma, boosted the survival of tumour-bearing mice and decreased various biochemical parameters associated with lung metastasis [130]. Berberine shows protective effects on lung injury induced by radiation means of intercellular adhesion molecular-1(ICAM-1) and TGF 31 in patients with lung cancer [131].
Azithromycin is an acid-stable macrolide antimicrobial drug which can be orally administered [132]. It reduces lung inflammation in mice suffering from cystic fibrosis and increases its survival [133]. This antibiotic attenuates the virulence of Pseudomonas aeruginosa, weakens its capability to form biofilms of fully polymerized alginate and upturns its sensitivity to complement and stationary-phase killing [134]. P. aeruginosa is one of the major opportunistic pathogens which can cause chronic lung infection, cystic fibrosis. Cystic fibrosis is initiated by a mutation in the conductance regulator gene in the transmembrane which encrypts a cyclic AMP-regulated chloride ion channel [135]. The formation of biofilm promotes cystic fibrosis development and limits the antimicrobial efficacies of current antibiotics. Berberine in a gut-dependent manner with azithromycin shows synergistic activity against $P$. Aeruginosa isolated from a patient's lung with cystic fibrosis in vitro and in vivo [136].

\section{Magnoflorine}

Magnoflorine is a quaternary benzylisoquinoline alkaloid of the aporphine structural subgroup which has been extracted from numerous species of the Menispermaceae family. It is an aporphine alkaloid, i.e. (S)-corytuberine in which the nitrogen has been quaternized by an additional methyl group. It has a role as a plant metabolite. It is an aporphine alkaloid and a quaternary ammonium ion. It is derived from (S)-corytuberine [137]. Acute lung injury (ALI) which is known worldwide as a severe respiratory disease accompanied by symptoms which include sepsis, neutrophilia and lung inflammation produced by bacteria, trauma, pneumonia and lipopolysaccharide. ALI is induced by various groups of stimulants like an endotoxin released from Gram-negative bacteria which cause intravascular coagulation, leukocytosis and endotoxic shock in mice. The results of histopathological changes and MPO activity showed that magnoflorine considerably alleviated the lung injury induced by lipopolysaccharides (LPS). Quantitative polymerase chain reaction (qPCR) analysis showed that this alkaloid dose-dependently reduced the pro-inflammatory cytokines IL- 6 , IL- $1 \beta$ and TNF- $\alpha$ expression. Immunofluorescence assay showed that LPS-induced levels of Toll-like receptor 4 (TLR4) were inhibited by magnoflorine treatment. The Western blotting technique used in order to detect the expression of MAPK and NF-kB signalling pathways exhibited that this alkaloid reduced the levels of phosphorylated p38, p65, extracellular signalregulated kinase(ERK), c-Jun amino-terminal kinases (JNK) and nuclear factor of kappa light polypeptide gene enhancer in $\beta$ cell inhibitor alpha ( $\mathrm{IkB} \alpha)$, which indicate that magnoflorine could protect against LPS-induced inflammation in ALI at least partially by inhibiting TLR4 mediated MAPK and NF-kB signalling pathways. ERK's 
role in cell division and of these enzyme inhibitors are being discovered as anticancer agents. The JNKs are critical regulators of transcription and p38 MAPKs are initiated by environmental stresses and inflammatory cytokines can contribute to autoimmunity and asthma $[138,139]$.

\section{Tetrahydropalmatine}

Tetrahydropalmatine (THP), an isoquinoline alkaloid is found in various plant species, significantly reduces the harmful effects of radiation and oxidative modification in the lungs. THP lessened the lung injury by inhibiting lung inflammation, apoptosis, cell recruitment in BALF and its protein levels, decreasing THP collagen content of lung tissues thus showing the protective effect of THP treatment for pulmonary fibrosis [140].

\section{Jatrorrhizine}

Jatrorrhizine is a protoberberine alkaloid [141]. Jatrorrhizine in thioacetamide-traumatized rat liver has been testified to have an anti-inflammatory effect and proven to recover blood flow as well as inducing mitotic activity. Jatrorrhizine has antifungal and antimicrobial activities. This alkaloid noncompetitively binds to the active site and inhibits monoamine oxidase [142]. It plays an acute neuroprotective role in apoptosis brought by $\mathrm{H}_{2} \mathrm{O}_{2}$ through its anti-oxidative actions and can be used as a novel therapeutic for its increased bioavailability to treat Alzheimer's disease [143, 144].

Thus, Isoquinoline alkaloids enable the reduction of pulmonary fibrosis by acting on various mechanisms that lead to the development of the disease. As a result, isoquinoline alkaloids can be used in prophylactic or therapeutic treatment for pulmonary fibrosis.

\section{Conclusion}

This review emphasizes on the beneficial effects of plants and their bioactive compounds that can be used for treating IPF where these plants' bioactive compounds exhibit prophylactic or therapeutic properties providing us a natural source to treat pulmonary fibrosis, replacing the use of synthetic drugs that cause side effects. To determine the effects of various bioactive compounds for treating pulmonary fibrosis, In vitro studies were performed on model organisms (mice, rat) which are induced with pulmonary fibrosis. Effects of plants and the bioactive compounds on pulmonary fibrosis were determined by measuring the extent of inflammation, collagen formation and oxidative stress. A wide range of factors which regulates pulmonary fibrosis such as hydroxyproline, collagen-I, NF-kB, PDGF, MMP-9, MCP-1, TIMPs, iNOS, $\alpha$-SMA, IкB, MAPK, PTEN, ICAM-1, TGF- $\beta$, TNF- $\alpha$, IFN and interleukins; SOD, catalase and glutathione-S-transferase; and MPO, MDA, ROS and RNS levels in pulmonary fibrosis-induced model organisms before and after administration of plant extract were measured. Bioactive compounds present in various plants which include isoquinoline alkaloids like berberine, magnoflorine, tetrahydropalmatine and jatrorrhizine present in plants Mahonia aquifolium, Tinospora cordifolia; $\beta$-caboline alkaloids present in Arenaria kansuensis; polysaccharides in Angelica Sinensis; lactones like ellagic acid present in Punica granatum; flavonoids in Passiflora edulis, Silybum marianum, Oxalis corniculata, Phyllanthus emblica, Citrus reticulate, Carthamus tinctorius L; triterpene acids in Eriobotrya japonica, Centella asiatica; fatty acids in Pistacia lentiscus, Linum usitatissimum; and catechins like epigallocatechin-3-gallate (EGCG) in Camellia sinensis possesses beneficial properties in treating IPF. Hence, the plants and their bioactive compounds mentioned above provide a promising therapeutic approach for IPF treatment.

\section{Abbreviations}

IPF: Idiopathic pulmonary fibrosis; ECM: Extracellular matrix; EMT: Epithelial mesenchymal transition; TNF-a: Tumour necrosis factor alpha; IL: Interleukins; TGF- $\beta$ : Transforming growth factor beta; MCP-1: Monocyte chemo attractant protein; IP-10: Interferon-gamma-inducible protein; ROS: Reactive oxygen species; Th 17: T helper cells; M1 and M2: Macrophages 1 and macrophages 2; MMP: Matrix metalloproteinases; PDGF: Platelet-derived growth factor; Th2: T helper type 2; IFN- $\gamma$ : Interferon gamma; WISP-1: WNT1-induciblesignalling pathway protein 1; WNT: Wingless-related integration site; PTEN: Phosphatase and tensin homologue; PI3Ks: Phosphoinositide 3-kinases; BLM: Bleomycin; $\mathrm{CCl}_{4}$ : Carbon tetrachloride; TIMP-1: Tissue inhibitor of metalloproteinase 1; MMP-9: Matrix metallopeptidase 9; SOD: Superoxide dismutase; MPO: Myeloperoxidase; MDA: Malondialdehyde; NF-KB: Nuclear factor kappa-light-chain-enhancer of activated B cells; a-SMA: Alpha-smooth muscle actin; EGCG: Epigallocatechin-3-gallat; AE2: Anion exchange protein 2; RNS: Reactive nitrogen species; CXCL: Chemokine (C-X-C motif) ligand: PCEB: Pistacia chinensis bark; BALF: Bronchoalveolar lavage fluid; DPPH: 1Diphenyl-2-picryl-hydrazyl; HSYA: Hydroxysafflor yellow A;

DOPA: Dihydroxyphenylalanine; NF- $\beta$ : Nuclear factor kappa $\beta$; iNOS: Inducible nitric oxide synthase; FAK: Adhesion kinase; PI3K/Akt: Phosphatidy linositol 3kinases; mTOR: Mammalian target of rapamycin; LC3-II: 1A/1B-light chain 3;

ICAM-1: Intercellular adhesion molecular-1; ALI: Acute lung injury;

AMP: Adenosine monophosphate; LPS: Lipopolysaccharides;

qPCR: Quantitative polymerase chain reaction; TLR4: Toll-like receptor 4; ERK: Extracellular signal regulated kinase; JNK: c-Jun amino-terminal kinases; IkBa: Nuclear factor of kappa light polypeptide gene enhancer in $\beta$ cell inhibitor alpha; MAPK: Mitogen-activated protein kinases;

THP: Tetrahydropalmatine; TIMP: Tissue inhibitor of metalloproteinases; Nrf2: Nuclear factor erythroid 2-related factor 2; Keap1: Kelch ECH associating protein 1; GPx: Glutathione peroxidase; CAT: Catalase; GSH: Glutathione; TBARS: Thiobarbituric acid reactive substances; POD: Peroxidase; NO: Nitric oxide; GST: Glutathione-S-transferase; IncRNA DANCR: Differentiation antagonizing non-protein coding RNA; CTGF: connective tissue growth factor

\section{Acknowledgements}

Not applicable

\section{Authors' contributions}

SSD and JBD conceptualized, designed and wrote the manuscript. VTC helped in writing the manuscript. SCK and VPK revised the manuscript and also major contributors in writing the manuscript. All authors have read and approved the manuscript.

Funding

Not applicable 


\section{Availability of data and materials}

Not applicable

\section{Declarations}

\section{Ethics approval and consent to participate}

Not applicable

\section{Consent for publication}

Not applicable

\section{Competing interests}

The authors declare that they have no competing interests.

\section{Author details}

'Department of Biotechnology, Vignan's Foundation for Science, Technology and Research, Vadlamudi, Guntur, Andhra Pradesh 522213, India.

2Department of Pathology, Government Medical College, Ongole, Andhra Pradesh, India. ${ }^{3}$ Department of Biotechnology, Vikrama Simhapuri University, Nellore, Andhra Pradesh 524320, India.

Received: 30 March 2021 Accepted: 10 July 2021

Published online: 03 August 2021

\section{References}

1. Takishima T (1994) Basic and clinical aspects of pulmonary fibrosis. CRC Press, Boca Raton, pp 501-502

2. Higashiyama H, Yoshimoto D, Kaise T, Matsubara S, Fujiwara M, Kikkawa H, Kinoshita M (2007) Inhibition of activin receptor-like kinase 5 attenuates bleomycin-induced pulmonary fibrosis. Exp Mol Pathol 83(1):39-46. https:// doi.org/10.1016/j.yexmp.2006.12.003

3. Hay ED (1991) Collagen and other matrix glycoproteins in embryogenesis. In: Cell biology of extracellular matrix. Springer, Boston, pp 419-462. https:// doi.org/10.1007/978-1-4615-3770-0_13

4. George PM, Patterson CM, Reed AK, Thillai M (2019) Lung transplantation for idiopathic pulmonary fibrosis. Lancet Respir Med 7(3):271-282. https:// doi.org/10.1016/S2213-2600(18)30502-2

5. Kuwano K, Kunitake R, Kawasaki M, Nomoto Y, Hagimoto N, Nakanishi Y, Hara N (1996) P21Waf1/Cip1/Sdi1 and p53 expression in association with DNA strand breaks in idiopathic pulmonary fibrosis. Am J Respir Crit Care Med 154(2):477-483. https://doi.org/10.1164/ajrccm.154.2.8756825

6. Van Wyk BE, Wink M (2004) Medicinal plants of the world. Briza Publications, Pretoria

7. Wynn TA (2011) Integrating mechanisms of pulmonary fibrosis. J Exp Med 208(7):1339-1350. https://doi.org/10.1084/jem.20110551

8. Gilmore MA (1991) Phases of wound healing. Dimens Oncol Nurs 5(3):32-34 PMID: 1823567

9. Steenfos HH (1994) Growth factors and wound healing. Scand J Plast Reconstr Surg Hand 28(2):95-105. https://doi.org/10.3109/028443194 09071186

10. Krafts KP (2010) Tissue repair: The hidden drama. Organogenesis 6(4):225233. https://doi.org/10.4161/org.6.4.12555

11. Willis BC, duBois RM, Borok Z (2006) Epithelial origin of myofibroblasts during fibrosis in the lung. Proc Am Thorac Soc 3(4):377-382. https://doi. org/10.1513/pats.200601-004TK

12. Li J, Chen J, Kirsner R (2007) Pathophysiology of acute wound healing. Clin Dermatol 25(1):9-18. https://doi.org/10.1016/j.clindermatol.2006.09.007

13. Guo SA, DiPietro LA (2010) Factors affecting wound healing. J Dent Res 89(3):219-229. https://doi.org/10.1177/0022034509359125

14. Martinon F (2008) Detection of immune danger signals by NALP3. J Leukoc Biol 83(3):507-511. https://doi.org/10.1189/jlb.0607362

15. Kolb M, Margetts PJ, Anthony DC, Pitossi F, Gauldie J (2001) Transient expression of $\mathrm{LL}-1 \beta$ induces acute lung injury and chronic repair leading to pulmonary fibrosis. J Clin Invest 107(12):1529-1536. https://doi.org/10.1172/ JCl12568

16. Simonian $\mathrm{PL}$, Roark $\mathrm{CL}$, Wehrmann F, Lanham AK, del Valle FD, Born WK Fontenot AP (2009) Th17-polarized immune response in a murine model of hypersensitivity pneumonitis and lung fibrosis. J Immunol 182(1):657-665. https://doi.org/10.4049/jimmunol.182.1.657
17. Martinez FO, Gordon S (2014) The M1 and M2 paradigm of macrophage activation: time for reassessment. F1000Prime Rep 6:13. https://doi.org/10.12 703/P6-13

18. Wynn TA, Barron L (2010) Macrophages: master regulators of inflammation and fibrosis. Semin Liver Dis 30(03):245-257. https://doi.org/10.1055/s-003 $0-1255354$

19. Song E, Ouyang N, Hörbelt M, Antus B, Wang M, Exton MS (2000) Influence of alternatively and classically activated macrophages on fibrogenic activities of human fibroblasts. Cell Immunol 204(1):19-28. https://doi.org/1 0.1006/cimm.2000.1687

20. Hancock A, Armstrong L, Gama R, Millar A (1998) Production of interleukin 13 by alveolar macrophages from normal and fibrotic lung. Am J Respir Cell Mol Biol 18(1):60-65. https://doi.org/10.1165/ajrcmb.18.1.2627

21. Cui H, Guo S, Banerjee S, Xie N, Liu RM, Thannickal VJ, Liu G (2019) Apolipoprotein E in Recruited Alveolar Macrophages Promotes Lung Fibrosis Resolution. C58. MECHANISMS OF PULMONARY FIBROSIS. Am Thorac Soc 199:5246-5246. https://doi.org/10.1164/ajrccm-conference.2019.1 99.1_MeetingAbstracts.A5246

22. Wynn TA, Vannella KM (2016) Macrophages in tissue repair, regeneration, and fibrosis. Immunity 44(3):450-462. https://doi.org/10.1016/j.immuni.2016.02.015

23. Jakubzick C, Choi ES, Joshi BH, Keane MP, KunkelSL PRK, Hogaboam CM (2003) Therapeutic attenuation of pulmonary fibrosis via targeting of IL-4and IL-13-responsive cells. J Immunol 171(5):2684-2693. https://doi.org/10.4 049/jimmunol.171.5.2684

24. Kolosowska N, Keuters MH, Wojciechowski S, Keksa-Goldsteine V, Laine M, Malm T, Dhungana H (2019) Peripheral administration of IL-13 induces antiinflammatory microglial/macrophage responses and provides neuroprotection in ischemic stroke. Neurotherapeutics 16(14):1304-1319. https://doi.org/10.1007/s13311-019-00761-0

25. Hayashi N, Yoshimoto T, Izuhara K, Matsui K, Tanaka T, Nakanishi K (2007) T helper 1 cells stimulated with ovalbumin and IL-18 induce airway hyperresponsiveness and lung fibrosis by IFN- $\gamma$ and IL-13 production. Proc Nat Acad Sci 104(37):14765-14770. https://doi.org/10.1073/pnas.0706378104

26. Konigshoff M, Balsara N, Pfaff EM, Kramer M, Chrobak I, Seeger W, Eickelberg $\mathrm{O}$ (2008) Functional Wnt signaling is increased in idiopathic pulmonary fibrosis. PLoS One 3(5):e2142. https://doi.org/10.1371/journal.pone.0002142

27. Konigshoff M, Kramer M, Balsara N, Wilhelm J, Amarie OV, Jahn A, Günther A (2009) WNT1-inducible signaling protein-1 mediates pulmonary fibrosis in mice and is upregulated in humans with idiopathic pulmonary fibrosis. J Clin Investig 119(4):772-787. https://doi.org/10.1172/JCI33950

28. Xia H, Diebold D, Nho R, Perlman D, Kleidon J, Kahm J, Henke C (2008) Pathological integrin signaling enhances proliferation of primary lung fibroblasts from patients with idiopathic pulmonary fibrosis. J Exp Med 205(7):1659-1672. https://doi.org/10.1084/jem.20080001

29. Pandit KV, Corcoran D, Yousef H, Yarlagadda M, Tzouvelekis A, Gibson KF, Richards T (2010) Inhibition and role of let-7d in idiopathic pulmonary fibrosis. Am J Respir Cell Mol Biol 182(2):220-229. https://doi.org/10.1164/ rccm.200911-16980C

30. Elewa YHA, Ichii O, Takada K, Nakamura T, Masum M, Kon Y (2018) Histopathological correlations between mediastinal fat-associated lymphoid clusters and the development of lung inflammation and fibrosis following bleomycin administration in mice. Front Immunol 9:271. https://doi.org/1 0.3389/fimmu.2018.00271

31. Umezawa H, Ishizuka M, Maeda K, Takeuchi T (1967) Studies on bleomycin. Cancer 20(5):891-895. https://doi.org/10.1002/1097-0142(1967)20:5<891::AIDCNCR2820200550>3.0.CO;2-V

32. Adamson IY (1976) Pulmonary toxicity of bleomycin. Environ Health Perspect 16:119-125. https://doi.org/10.1289/ehp.7616119

33. Xu Q, Liu Y, Pan H, Xu T, Li Y, Yuan J, Ni C (2019) Aberrant expression of miR-125a-3p promotes fibroblast activation via Fyn/STAT3 pathway during silica-induced pulmonary fibrosis. Toxicology 414:57-67. https://doi.org/10.1 016/j.tox.2019.01.007

34. Bismuth C, Garnier R, Baud FJ, Muszynski J, Keyes C (1990) Paraquat poisoning. Drug Saf 5(4):243-251. https://doi.org/10.2165/00002018-1 99005040-00002

35. Cantor JO, Osman M, Cerreta JM, Suarez R, Mandl I, Turino GM (1984) Amiodarone-induced pulmonary fibrosis in hamsters. Exp Lung Res 6(1):110. https://doi.org/10.1016/j.rmcr.2019.01.014

36. Qian P, Hong Peng C, Ye X (2019) Interstitial pneumonia induced by cyclophosphamide: A case report and review of the literature. Respir Med Case Rep 26:212-214. https://doi.org/10.1016/j.rmcr.2019.01.014 
37. Uchida M, Shiraishi H, Ohta S, Arima K, Taniguchi K, Suzuki S, Toda S (2012) Periostin, a matricellular protein, plays a role in the induction of chemokines in pulmonary fibrosis. Am J Respir Cell Mol Biol 46(5):677-686 https://doi. org/10.1165/rcmb.2011-01150C

38. Paakko P, Sormunen R, Risteli L, Risteli J, Ala-Kokko L, Ryhänen L (1989) Malotilate prevents accumulation of type III pN-collagen, type IV collagen, and laminin in carbon tetrachloride-induced pulmonary fibrosis in rats. Am J Respir Crit Care Med 139(5):1105-1111 https://doi.org/10.1164/ajrccm/139. 5.1105

39. Das M, Boerma M, Goree JR, Lavoie EG, Fausther M, Gubrij IB, Dranoff JA (2014) Pathological changes in pulmonary circulation in carbon tetrachloride (CCl4)-induced cirrhotic mice. PLoS One 9(4):e96043. https:// doi.org/10.1371/journal.pone.0096043

40. Chow LN, Schreiner P, Ng BY, Lo B, Hughes MR, Scott RW, Barta I (2016) Impact of a CXCL12/CXCR4 antagonist in bleomycin (BLM) induced pulmonary fibrosis and carbon tetrachloride (CCL4) induced hepatic fibrosis in mice. PLoS One 11(3):e0151765. https://doi.org/10.13 71/journal.pone.0151765

41. Kim HR, Lee K, Park CW, Song JA, Park YJ, Chung KH (2016) Polyhexamethylene guanidine phosphate aerosol particles induce pulmonary inflammatory and fibrotic responses. Arch Toxicol 90(3):617-632 https://doi.org/10.1007/s00204-015-1486-9

42. Johnston CJ, Williams JP, Okunief P, Finkelstein JN (2002) Radiation-induced pulmonary fibrosis: examination of chemokine and chemokine receptor families. Radiat Res 157(3):256-265. https://doi.org/10.1667/0033-7587(2002 )157[0256:RIPFEO]2.0.CO;2

43. Le LC, Le MB, Fauroux B, Forenza N, Dommergues JP, Desbois JC, Pin I (2000) Long-term outcome of idiopathic pulmonary hemosiderosis in children. Medicine 79(5):318-326. https://doi.org/10.1097/00005792-2 00009000-00005

44. Lynch DA, Godwin JD, Safrin S, Starko KM, Hormel P, Brown KK, Webb WR (2005) High-resolution computed tomography in idiopathic pulmonary fibrosis: diagnosis and prognosis. Am J Respir Crit Care Med 172(4):488-493. https://doi.org/10.1164/rccm.200412-17560C

45. Murata I, Ito K, Takenaka K, Yoshinoya S, Kikuchi K, Kiuchi T, Tanigawa T (1997) Clinical evaluation of pulmonary hypertension in systemic sclerosis and related disorders: a Doppler echocardiographic study of 135 Japanese patients. Chest 111(1):36-43. https://doi.org/10.1378/chest.111.1.36

46. D'Andrea A, Stanziola AA, Saggar R, Saggar R, Sperlongano S, Conte M, Bossone $E$ (2019) Right ventricular functional reserve in early-stage idiopathic pulmonary fibrosis: an exercise two-dimensional speckle tracking doppler echocardiography study. Chest 155(2):297-306. https://doi.org/10.1 016/j.chest.2018.11.015

47. Xaubet A, Agusti C, Luburich P, Roca J, Monton C, Ayuso MC, RodriguezRoisin R (1998) Pulmonary function tests and CT scan in the management of idiopathic pulmonary fibrosis. Am J Respir Crit Care Med 158(2):431-436. https://doi.org/10.1164/ajrccm.158.2.9709008

48. Bonella F, di Marco F, Spagnolo P (2019) Pulmonary Function Tests in Idiopathic Pulmonary Fibrosis. In: Meyer K, Nathan S (eds) Idiopathic Pulmonary Fibrosis. Respiratory Medicine. Humana Press, Cham, pp 85-95. https://doi.org/10.1007/978-3-319-99975-3_5

49. Zisman DA, Ross DJ, Belperio JA, Saggar R, Lynch JP III, Ardehali A, Karlamangla AS (2007) Prediction of pulmonary hypertension in idiopathic pulmonary fibrosis. Respir Med 101(10):2153-2159. https://doi.org/10.1016/j. rmed.2007.05.012

50. Marcus CL, Bader D, Stabile MW, Wang Cl, Osher AB, Keens TG (1992) Supplemental oxygen and exercise performance in patients with cystic fibrosis with severe pulmonary disease. Chest 101(1):52-57. https://doi.org/1 0.1378/chest.101.1.52

51. Costa CM, Neder JA, Verrastro CG, Paula-Ribeiro M, Ramos R, Ferreira EM, Ota-Arakaki J (2019) Uncovering the mechanisms of exertional dyspnoea in combined pulmonary fibrosis and emphysema. Eur Respir J 55(1):1901319. https://doi.org/10.1183/13993003.01319-2019

52. Zajaczkowska M, Johnson A, Gallur L, Shin J, Henderson C, Williamson J (2019) Transbronchial lung cryobiopsy: a novel confirmatory tool to diagnose asbestos-related pulmonary fibrosis. Respirol Case Rep 7(1):e00380. https://doi.org/10.1002/rcr2.380

53. Ravaglia C, Tomassetti S, Poletti V (2019) New idiopathic pulmonary fibrosis guidelines: Are cryobiopsy and surgery competitive in clinical practice? Am J Respir Crit Care Med 199(5):666-667. https://doi.org/10.1164/rccm.201 809-1718LE
54. Richeldi L, Davies HRH, Spagnolo P, Luppi F (2003) Corticosteroids for idiopathic pulmonary fibrosis. Cochrane Database Syst Rev (3). https://doi. org/10.1002/14651858.CD002880

55. Raghu G, Depaso WJ, Cain K, Hammar SP, Wetzel CE, Dreis DF, Winterbauer $\mathrm{RH}$ (1991) Azathioprine combined with prednisone in the treatment of idiopathic pulmonary fibrosis: a prospective double-blind, randomized, placebo-controlled clinical trial. Am Rev Respir Dis 144(2):291-296. https:// doi.org/10.1164/ajrccm/144.2.291

56. Raghu G, Brown KK, Costabel U, Cottin V, Du Bois RM, Lasky JA, Fatenejad S (2008) Treatment of idiopathic pulmonary fibrosis with etanercept: an exploratory, placebo-controlled trial. Am J Respir Crit Care Med 178(9):948955. https://doi.org/10.1164/rccm.200709-14460C

57. Gurujeyalakshmi G, Giri SN (1995) Molecular mechanisms of antifibrotic effect of interferon gamma in bleomycin-mouse model of lung fibrosis: downregulation of TGF- $\beta$ and procollagen I and III gene expression. Exp Lung Res 21(5):791-808. https://doi.org/10.3109/01902149509050842

58. Jackson RM, Glassberg MK, Ramos CF, Bejarano PA, Butrous G, Gómez-Marin O (2010) Sildenafil therapy and exercise tolerance in idiopathic pulmonary fibrosis. Lung 188(2):115-123. https://doi.org/10.1007/s00408-009-9209-8

59. Corte TJ, Keir GJ, Dimopoulos K, Howard L, Corris PA, Parfitt L, Maher TM (2014) Bosentan in pulmonary hypertension associated with fibrotic idiopathic interstitial pneumonia. Am J Respir Crit Care Med 190(2):208-217. https://doi.org/10.1164/rccm.201403-04460C

60. Raghu G, Million-Rousseau R, Morganti A, Perchenet L, Behr J (2013) Macitentan for the treatment of idiopathic pulmonary fibrosis: the randomised controlled MUSIC trial. Eur Respir J 42(6):1622-1632. https://doi. org/10.1183/09031936.00104612

61. Raghu G, Behr J, Brown KK, Egan JJ, Kawut SM, Flaherty KR, Costabel U (2013) Treatment of idiopathic pulmonary fibrosis with ambrisentan. Ann Intern Med 158(9):641-649. https://doi.org/10.7326/0003-4819-158-9-2013 05070-00003

62. Oldham JM, Ma SF, Martinez FJ, Anstrom KJ, Raghu G, Schwartz DA, Huang Y (2015) TOLLIP, MUC5B, and the response to N-acetylcysteine among individuals with idiopathic pulmonary fibrosis. Am J Respir Crit Care Med 192(12):1475-1482. https://doi.org/10.1164/rccm.201505-10100C

63. Noth I, Anstrom KJ, Calvert SB, De Andrade J, Flaherty KR, Glazer C, Olman MA (2012) A placebo-controlled randomized trial of warfarin in idiopathic pulmonary fibrosis. Am J Respir Crit Care Med 186(1):88-95. https://doi. org/10.1164/rccm.201202-03140C

64. Daniels CE, Lasky JA, Limper AH, Mieras K, Gabor E, Schroeder DR (2010) Imatinib treatment for idiopathic pulmonary fibrosis: randomized placebocontrolled trial results. Am J Respir Crit Care Med 181(6):604-610. https:// doi.org/10.1164/rccm.200906-09640C

65. Raghu G, Wells AU, Nicholson AG, Richeldi L, Flaherty KR, Le Maulf F, Hansell DM (2017) Effect of nintedanib in subgroups of idiopathic pulmonary fibrosis by diagnostic criteria. Am J Respir Crit Care Med 195(1):78-85. https://doi.org/10.1164/rccm.201602-0402OC

66. Noble PW, Albera C, Bradford WZ, Costabel U, Glassberg MK, Kardatzke D, Valeyre D (2011) Pirfenidone in patients with idiopathic pulmonary fibrosis (CAPACITY): two randomised trials. Lancet 377(9779):1760-1769. https://doi. org/10.1016/S0140-6736(11)60405-4

67. Eickelberg O, Pansky A, Koehler E, Bihl M, Tamm M, Hildebrand P, Roth M (2001) Molecular mechanisms of TGF- $\beta$ antagonism by interferon $\gamma$ and cyclosporine A in lung fibroblasts. FASEB J 15(3):797-806. https://doi.org/1 0.1096/fj.00-0233com

68. Nagano J, lyonaga K, Kawamura K, Yamashita A, Ichiyasu H, Okamoto T, Kohrogi H (2006) Use of tacrolimus, a potent antifibrotic agent, in bleomycin-induced lung fibrosis. Eur Respir J 27(3):460-469. https://doi. org/10.1183/09031936.06.00070705

69. Arai T, InoueY SY, Tachibana K, Nakao K, Sugimoto C, Hayashi S (2014) Predictors of the clinical effects of pirfenidone on idiopathic pulmonary fibrosis. Respir Investig 52(2):136-143. https://doi.org/10.1016/j.resinv.2013. 09.002

70. Ogura T, Taniguchi H, Azuma A, Inoue Y, Kondoh Y, Hasegawa Y, Kluglich M (2015) Safety and pharmacokinetics of nintedanib and pirfenidone in idiopathic pulmonary fibrosis. Eur Respir J 45(5):1382-1392. https://doi.org/1 0.1183/09031936.00198013

71. Zhao L, Wang X, Chang Q, Xu J, Huang Y, Guo Q, Wang J (2010) Neferine, a bisbenzylisoquinline alkaloid attenuates bleomycin-induced pulmonary fibrosis. Eur J Pharmacol 627(1-3):304-312. https://doi.org/10.1016/j.ejphar.2 009.11 .007 
72. Cui Y, Shen N, Dang J, Mei L, Tao Y, Liu Z (2017) Anti-inflammatory bioactive equivalence of combinatorial components $\beta$-carboline alkaloids identified in Arenaria kansuensis by two-dimensional chromatography and solid-phase extraction coupled with liquid-liquid extraction enrichment technology. J Sep Sci 40(14):2895-2905. https://doi.org/10.1002/jssc.201 700144

73. Cui $Y$, Jiang $L, Y u R$, Shao $Y$, Mei $L$, Tao Y (2019) $\beta$-carboline alkaloids attenuate bleomycin induced pulmonary fibrosis in mice through inhibiting NF-kb/p65 phosphorylation and epithelial-mesenchymal transition. J Ethnopharmacol 243:112096. https://doi.org/10.1016/j.jep.2019.112096

74. Godevac D, Damjanovic A, Stanojkovic TP, Andelkovic B, Zdunic G (2018) Identification of cytotoxic metabolites from Mahonia aquifolium using $1 \mathrm{H}$ NMR-based metabolomics approach. J Pharm Biomed Anal 150:9-14. https://doi.org/10.1016/j.jpba.2017.11.075

75. Petruczynik A, Plech T, Tuzimski T, Misiurek J, Kaproń B, Misiurek D, Waksmundzka-Hajnos M (2019) Determination of Selected Isoquinoline Alkaloids from Mahonia Aquifolia; Meconopsis Cambrica; Corydalis Lutea; Dicentra Spectabilis; Fumaria Officinalis; Macleaya Cordata Extracts by HPLCDAD and Comparison of Their Cytotoxic Activity. Toxins 11(10):575. https:// doi.org/10.3390/toxins11100575

76. Chitra P, Saiprasad G, Manikandan R, Sudhandiran G (2013) Berberine attenuates bleomycin induced pulmonary toxicity and fibrosis via suppressing NF-KB dependant TGF- $\beta$ activation: a biphasic experimental study. Toxicol Lett 219(2):178-193. https://doi.org/10.1016/j.toxlet.2013. 03.009

77. Chakraborty K, Dey A, Bhattacharyya A, Dasgupta SC (2019) Anti-fibrotic effect of black tea (Camellia sinensis) extract in experimental pulmonary fibrosis. Tissue Cell 56:14-22. https://doi.org/10.1016/j.tice.2018.11.006

78. Khan S, Parvez S, Chaudhari B, Ahmad F, Anjum S, Raisuddin S (2013) Ellagic acid attenuates bleomycin and cyclophosphamide-induced pulmonary toxicity in Wistar rats. Food Chem Toxicol 58:210-219. https://doi.org/10.101 6/j.fct.2013.03.046

79. Hemmati AA, Rezaie A, Darabpour P (2013) Preventive effects of pomegranate seed extract on bleomycin-induced pulmonary fibrosis in rat. Jundishapur J Nat Pharm Prod 8(2):76 PMID: 24624192; PMCID: PMC3941905

80. Surolia R, Li FJ, Wang Z, Li H, Dsouza K, Thomas V, Antony VB (2019) Vimentin intermediate filament assembly regulates fibroblast invasion in fibrogenic lung injury. JCl insight 4(7). https://doi.org/10.1172/jci.insight.123253

81. Minguzzi S, Barata LE, Shin YG, Jonas PF, Chai HB, Park EJ, Cordell GA (2002) Cytotoxic withanolides from Acnistus arborescens. Phytochemistry 59(6):635641. https://doi.org/10.1016/S0031-9422(02)00022-5

82. Alali FQ, Amrine CSM, El-Elimat T, Alkofahi A, Tawaha K, Gharaibah M, Oberlies NH (2014) Bioactive withanolides from Withania obtusifolia. Phytochem Lett 9:96-101. https://doi.org/10.1016/j.phytol.2014.05.002

83. Naz K, Khan MR, Shah NA, Sattar S, Noureen F, Awan ML (2014) Pistacia chinensis: A potent ameliorator of $\mathrm{CCl} 4$ induced lung and thyroid toxicity in rat model. Biomed Res Int 2014:1-13. https://doi.org/10.1155/2014/192906

84. Bahri S, Ben Ali R, Gasmi K, Mlika M, Fazaa S, Ksouri R, Shlyonsky V (2017) Prophylactic and curative effect of rosemary leaves extract in a bleomycin model of pulmonary fibrosis. Pharm Biol 55(1):462-471. https://doi.org/10.1 080/13880209.2016.1247881

85. Abidi A, Robbe A, Kourda N, Khamsa SB, Legrand A (2017) Nigella sativa, a traditional Tunisian herbal medicine, attenuates bleomycin-induced pulmonary fibrosis in a rat model. Biomed Pharmacother 90:626-637. https://doi.org/10.1016/j.biopha.2017.04.009

86. Abidi A, Aissani N, Sebai H, Serairi R, Kourda N, Ben Khamsa S (2017) Protective effect of Pistacia lentiscus oil against bleomycin-induced lung fibrosis and oxidative stress in rat. Nutr Cancer 69(3):490-497. https://doi. org/10.1080/01635581.2017.1283423

87. Abidi A, Serairi R, Kourda N, Ben Ali R, Ben Khamsa S, Feki M (2016) Therapeutic effect of flaxseed oil on experimental pulmonary fibrosis induced by bleomycin in rats. Eur J Inflamm 14(2):133-143. https://doi.org/1 $0.1177 / 1721727 \times 16652147$

88. Chilakapati SR, Serasanambati M, Manikonda PK, Chilakapati DR, Watson RR (2014) Passion fruit peel extract attenuates bleomycin-induced pulmonary fibrosis in mice. Can J Physiol Pharmacol 92(8):631-639. https://doi.org/1 0.1139/cjpp-2014-0006

89. Li XH, Xiao T, Yang JH, Qin Y, Gao JJ, Liu HJ, Zhou HG (2018) Parthenolide attenuated bleomycin-induced pulmonary fibrosis via the NF-kB/Snail signaling pathway. Respir Res 19(1):111. https://doi.org/10.1186/s12931-0180806-z
90. Punithavathi D, Venkatesan N, Babu M (2000) Curcumin inhibition of bleomycin-induced pulmonary fibrosis in rats. Br J Pharmacol 131(2):169_ 172. https://doi.org/10.1038/sj.bjp.0703578

91. Chen $M$, Cheung FW, Chan MH, Hui PK, Ip SP, Ling YH, Liu WK (2012) Protective roles of Cordyceps on lung fibrosis in cellular and rat models. J Ethnopharmacol 143(2):448-454. https://doi.org/10.1016/j.jep.2 012.06 .033

92. Bahri S, Ben Ali R, Nahdi A, Mlika M, Abdennabi R, Jameleddine S (2020) Salvia officinalis attenuates bleomycin-induced oxidative stress and lung fibrosis in rats. Nutr Cancer 72(7):1135-1145. https://doi.org/10.1080/0163 5581.2019 .1675724

93. Razavi-Azarkhiavi K, Ali-Omrani M, Solgi R, Bagheri P, Haji-Noormohammadi M, Amani N, Sepand MR (2014) Silymarin alleviates bleomycin-induced pulmonary toxicity and lipid peroxidation in mice. Pharm Biol 52(10):12671271. https://doi.org/10.3109/13880209.2014.889176

94. Wianowska D, Wisniewski M (2014) Simplified procedure of silymarin extraction from Silybum marianum L. Gaertner. J Chromatogr Sci 53(2):366372. https://doi.org/10.1093/chromsci/bmu049

95. Mizokami H, Tomita-Yokotani K, Yoshitama K (2008) Flavonoids in the leaves of Oxalis corniculata and sequestration of the flavonoids in the wing scales of the pale grass blue butterfly, Pseudozizeeria maha. Int J Plant Res 121(1): 133-136 https://doi.org/10.1007/s10265-007-0132-x

96. Srinivasan GV, Unnikrishnan KP, Shree AR, Balachandran I (2008) HPLC estimation of berberine in Tinospora cordifolia and Tinospora sinensis. Indian J Pharm Sci 70(1):96. https://doi.org/10.4103/0250-474X.40341

97. Khan MT, Lampronti I, Martello D, Bianchi N, Jabbar S, Choudhuri MSK, Gambari R (2002) Identification of pyrogallol as an antiproliferative compound present in extracts from the medicinal plant Emblica officinalis: effects on in vitro cell growth of human tumor cell lines. Int J Oncol Res 21(1):187-192. https://doi.org/10.3892/ijo.21.1.187

98. Tahir I, Khan MR, Shah NA, Aftab M (2016) Evaluation of phytochemicals, antioxidant activity and amelioration of pulmonary fibrosis with Phyllanthus emblica leaves. BMC Complement Altern Med 16(1):406. https://doi.org/1 0.1186/s12906-016-1387-3

99. Qian W, Cai X, Qian Q, Wang D, Zhang L (2020) Angelica sinensis polysaccharide suppresses epithelial-mesenchymal transition and pulmonary fibrosis via a DANCR/AUF-1/FOXO3 regulatory axis. Aging Dis 11(1):17. https://doi.org/10.14336/2FAD.2019.0512

100. Zhou XM, Wen GY, Zhao Y, Liu YM, Li JX (2013) Inhibitory effects of alkaline extract of Citrus reticulata on pulmonary fibrosis. J Ethnopharmacol 146(1): 372-378. https://doi.org/10.1016/j.jep.2013.01.006

101. Tumbas VT, Cetkovic GS, Djilas SM, Canadanovic-Brunet JM, VulicJJ KZ, Skerget M (2010) Antioxidant activity of mandarin (Citrus reticulata) peel. Acta Period Technol 41:195-203. https://doi.org/10.2298/APT1041195T

102. Ng LT, Yen FL, Liao CW, Lin CC (2007) Protective effect of Houttuynia cordata extract on bleomycin-induced pulmonary fibrosis in rats. Am J Chinese Med 35(03):465-475. https://doi.org/10.1142/S0192415X07004989

103. Jin M, Wu Y, Wang L, Zang B, Tan L (2016) Hydroxysafflor Yellow A attenuates bleomycin-induced pulmonary fibrosis in mice. Phytother Res 30(4):577-587. https://doi.org/10.1002/ptr.5560

104. Yang Y, HuangY HC, Lv X, Liu L, Wang Y, Li J (2012) Antifibrosis effects of triterpene acids of Eriobotrya japonica (Thunb.) Lindl. leaf in a rat model of bleomycin-induced pulmonary fibrosis. J Pharm Pharmacol 64(12):17511760. https://doi.org/10.1111/j.2042-7158.2012.01550.X

105. Lu GX, Bian DF, Ji Y, Guo JM, Wei ZF, Jiang SD, Dai Y (2014) Madecassoside ameliorates bleomycin-induced pulmonary fibrosis in mice by downregulating collagen deposition. Phytother Res 28(8):1224-1231. https://doi.org/10.1002/ptr.5120

106. You H, Wei L, Sun WL, Wang L, Yang ZL, Liu Y, Zhang WJ (2014) The green tea extract epigallocatechin-3-gallate inhibits irradiation-induced pulmonary fibrosis in adult rats. Int J Mol Med 34(1):92-102. https://doi.org/10.3892/ ijmm.2014.1745

107. Dona M, Dell Aica I, Calabrese F, Benelli R, Morini M, Albini A, Garbisa S (2003) Neutrophil restraint by green tea: inhibition of inflammation, associated angiogenesis, and pulmonary fibrosis. J Immunol 170(8):43354341. https://doi.org/10.4049/jimmunol.170.8.4335

108. Sriram N, Kalayarasan S, Sudhandiran G (2009) Epigallocatechin-3-gallate exhibits anti-fibrotic effect by attenuating bleomycin-induced glycoconjugates, lysosomal hydrolases and ultrastructural changes in rat model pulmonary fibrosis. Chem Biol Interact 180(2):271-280. https://doi. org/10.1016/j.cbi.2009.02.017 
109. Qin S, Alcorn JF, Craigo JK, Tjoeng C, Tarwater PM, Kolls JK, Reinhart TA (2011) Epigallocatechin-3-gallate reduces airway inflammation in mice through binding to proinflammatory chemokines and inhibiting inflammatory cell recruitment. J Immunol 186(6):3693-3700. https://doi. org/10.4049/jimmunol.1002876

110. Borden P, Solymar D, Sucharczuk A, Lindman B, Cannon P, Heller RA (1996) Cytokine control of interstitial collagenase and collagenase-3 gene expression in human chondrocytes. J Biol Chem 271(38):23577-23581. https://doi.org/10.1074/jbc.271.38.23577

111. Saadane A, Masters S, Di Donato J, Li J, Berger M (2007) Parthenolide inhibits IKB kinase, NF-KB activation, and inflammatory response in cystic fibrosis cells and mice. Am J Respir Cell Mol Biol 36(6):728-736. https://doi. org/10.1165/rcmb.2006-03230C

112. Aggarwal BB, Harikumar KB (2009) Potential therapeutic effects of curcumin, the anti-inflammatory agent, against neurodegenerative, cardiovascular, pulmonary, metabolic, autoimmune and neoplastic diseases. Int J Biochem Cell Biol 41(1):40-59. https://doi.org/10.1016/j.biocel.2008.06.010

113. Hewlings SJ, Kalman DS (2017) Curcumin: a review of its' effects on human health. Foods 6(10):92. https://doi.org/10.3390/foods6100092

114. Smith MR, Gangireddy SR, Narala VR, Hogaboam CM, Standiford TJ, Christensen PJ, Reddy RC (2010) Curcumin inhibits fibrosis-related effects in IPF fibroblasts and in mice following bleomycin-induced lung injury. Am J Phys Lung Cell Mol Phys 298(5):616-625. https://doi.org/10.1152/ajplung. 00002.2009

115. Zhang XL, Bi-Cheng L, Al-Assaf S, Phillips GO, Phillips AO (2012) Cordyceps sinensis decreases TGF- $\beta 1$ dependent epithelial to mesenchymal trans differentiation and attenuates renal fibrosis. Food Hydrocoll 28(1):200-212. https://doi.org/10.1016/j.foodhyd.2011.12.016

116. Liu Y, Wang J, Wang W, Zhang H, Zhang X, Han C (2015) The chemical constituents and pharmacological actions of Cordyceps sinensis. Evid Based Complement Alternat Med 2015:1-12. https://doi.org/10.1155/2015/575063

117. Ahmad B, Khan MR, Shah NA (2015) Amelioration of carbon tetrachlorideinduced pulmonary toxicity with Oxalis corniculata. Toxicol Ind Health 31(12):1243-1251. https://doi.org/10.1177/0748233713487245

118. Yang L, Jiang JG (2009) Bioactive components and functional properties of Hottuynia cordata and its applications. Pharm Biol 47(12):1154-1161. https:// doi.org/10.3109/13880200903019200

119. Delshad E, Yousefi M, Sasannezhad P, Rakhshandeh H, Ayati Z (2018) Medical uses of Carthamus tinctorius L.(safflower): a comprehensive review from traditional medicine to modern medicine. Electron Physician 10(4): 6672. https://doi.org/10.19082/6672

120. Kuo CL, Chi CW, Liu TY (2004) The anti-inflammatory potential of berberine in vitro and in vivo. Cancer Lett 203(2):127-137. https://doi.org/10.1016/j.ca nlet.2003.09.002

121. Zhang XY, Shimura S, Masuda T, Saitoh H, Shirato K (2000) Antisense Oligonucleotides to NF-K B Improve Survival in Bleomycin-induced Pneumopathy of the Mouse. Am J Respir Crit Care Med 162(4):1561-1568. https://doi.org/10.1164/ajrccm.162.4.9908093

122. Massaous J, Hata A (1997) TGF- $\beta$ signalling through the Smad pathway. Trends Cell Biol 7(5):187-192. https://doi.org/10.1016/S0962-8924(97)01036-2

123. Wrana JL, Attisano L (2000) The smad pathway. Cytokine Growth Factor Rev 11(1-2):5-13. https://doi.org/10.1016/S1359-6101(99)00024-6

124. Chitra P, Saiprasad G, Manikandan R, Sudhandiran G (2015) Berberine inhibits Smad and non-Smad signaling cascades and enhances autophagy against pulmonary fibrosis. J Mol Med 93(9):1015-1031. https://doi.org/10.1 007/s00109-015-1283-1

125. Chu EC, Tarnawski AS (2004) PTEN regulatory functions in tumor suppression and cell biology. Med Sci Monit 10(10):235-241 PMID: 15448614

126. Miyoshi K, Yanagi S, Kawahara K, Nishio M, Tsubouchi H, Imazu Y, Suzuki A (2013) Epithelial Pten controls acute lung injury and fibrosis by regulating alveolar epithelial cell integrity. Am J Respir Crit Care Med 187(3):262-275. https://doi.org/10.1164/rccm.201205-08510C

127. Parapuram SK, Thompson K, Tsang M, Hutchenreuther J, Bekking C, Liu S, Leask A (2015) Loss of PTEN expression by mouse fibroblasts results in lung fibrosis through a CCN2-dependent mechanism. Matrix Biol 43:35-41. https://doi.org/10.1016/j.matbio.2015.01.017

128. Jiang ZF, Shao LJ, Wang WM, Yan XB, Liu RY (2012) Decreased expression of Beclin-1 and LC3 in human lung cancer. Mol Biol Rep 39(1):259-267 https:// doi.org/10.1007/s11033-011-0734-1

129. Potez M, Trappetti V, Bouchet A, Fernandez-Palomo C, Guc E, Kilarski WW, Djonov V (2018) Characterization of a B16-F10 melanoma model locally implanted into the ear pinnae of C57BL/6 mice. PLoS One 13(11):e0206693. https://doi.org/10.1371/journal.pone.0206693

130. Hamsa TP, Kuttan G (2012) Berberine inhibits pulmonary metastasis through down-regulation of MMP in metastatic B16F-10 melanoma cells. Phytother Res 26(4):568-578. https://doi.org/10.1002/ptr.3586

131. Liu Y, Yu H, Zhang C, Cheng Y, Hu L, Meng X, Zhao Y (2008) Protective effects of berberine on radiation-induced lung injury via intercellular adhesion molecular- 1 and transforming growth factor-beta- 1 in patients with lung cancer. Eur J Cancer 44(16):2425-2432 https://doi.org/10.1016/j. ejca.2008.07.040

132. Peters DH, Friedel HA, McTavish D (1992) Azithromycin. Drugs 44(5):750799. https://doi.org/10.2165/00003495-199244050-00007

133. Tsai WC, Hershenson MB, Zhou Y, Sajjan U (2009) Azithromycin increases survival and reduces lung inflammation in cystic fibrosis mice. Inflamm Res 58(8):491-501. https://doi.org/10.1007/s00011-009-0015-9

134. Hoffmann N, Lee B, Hentzer M, Rasmussen TB, Song Z, Johansen HK, Høiby N (2007) Azithromycin blocks quorum sensing and alginate polymer formation and increases the sensitivity to serum and stationery-growthphase killing of Pseudomonas aeruginosa and attenuates chronic P. aeruginosa lung infection in Cftr-/- mice. Antimicrob Agents Chemother 51(10):3677-3687. https://doi.org/10.1128/AAC.01011-06

135. Folkesson A, Jelsbak L, Yang L, Johansen HK, Ciofu O, Hoiby N, Molin S (2012) Adaptation of Pseudomonas aeruginosa to the cystic fibrosis airway: an evolutionary perspective. Nat Rev Microbiol 10(12):841. https://doi.org/1 $0.1038 /$ nrmicro2907

136. Li Y, Huang J, Li L, Liu L (2017) Synergistic activity of berberine with azithromycin against Pseudomonas aeruginosa isolated from patients with cystic fibrosis of lung in vitro and in vivo. Cell Physiol Biochem 42(4):16571669. https://doi.org/10.1159/000479411

137. Nakano T (1954) Studies on the Alkaloids of Magnoliaceous Plants. XIII.: Alkaloids of Magnolia grandiflora L. (2). Pharm Bull 2(4):326-328. https://doi. org/10.1248/cpb1953.2.326

138. Johnson GL, Lapadat R (2002) Mitogen-activated protein kinase pathways mediated by ERK, JNK, and p38 protein kinases. Science 298(5600):19111912. https://doi.org/10.1126/science.1072682

139. Christian F, Smith EL, Carmody RJ (2016) The regulation of NF-KB subunits by phosphorylation. Cells 5(1):12. https://doi.org/10.3390/cells5010012

140. Yu J, Che J, Liu L, Yang F, Zhu X, Cao B (2016) Tetrahydropalmatine attenuates irradiation induced lung injuries in rats. Life Sci 153:74-81. https://doi.org/10.1016/j.lfs.2016.03.056

141. Ruffer M, Ekundayo O, Nagakura N, Zenk MH (1983) Biosynthesis of the protoberberine alkaloid jatrorrhizine. Tetrahedron Lett (26):2643-2644

142. Tan RX, Meng J C, Hostettmann K (2000) Phytochemical investigation of some traditional Chinese medicines and endophyte cultures. Pharm Biol, 38(sup1):25-32. https://doi.org/10.1076/phbi.38.6.25.5955.

143. Luo T, Shen XY, Li S, Ouyang T, Mai QA, Wang HQ (2017) The protective effect of jatrorrhizine against oxidative stress in primary rat cortical neurons. CNS Neurol Disord Drug Targets 16(5):617-623. https://doi.org/10.2174/1871 527315666160711101210

144. Ahmad A, Husain A, Mujeeb M, Khan SA, Najmi AK, Siddique NA, Damanhouri ZA, Anwar F (2013) A review on therapeutic potential of Nigella sativa: A miracle herb. Asian Pac J Trop Biomed 3(5):337-352. https:// doi.org/10.1016/S2221-1691(13)60075-1

\section{Publisher's Note}

Springer Nature remains neutral with regard to jurisdictional claims in published maps and institutional affiliations. 